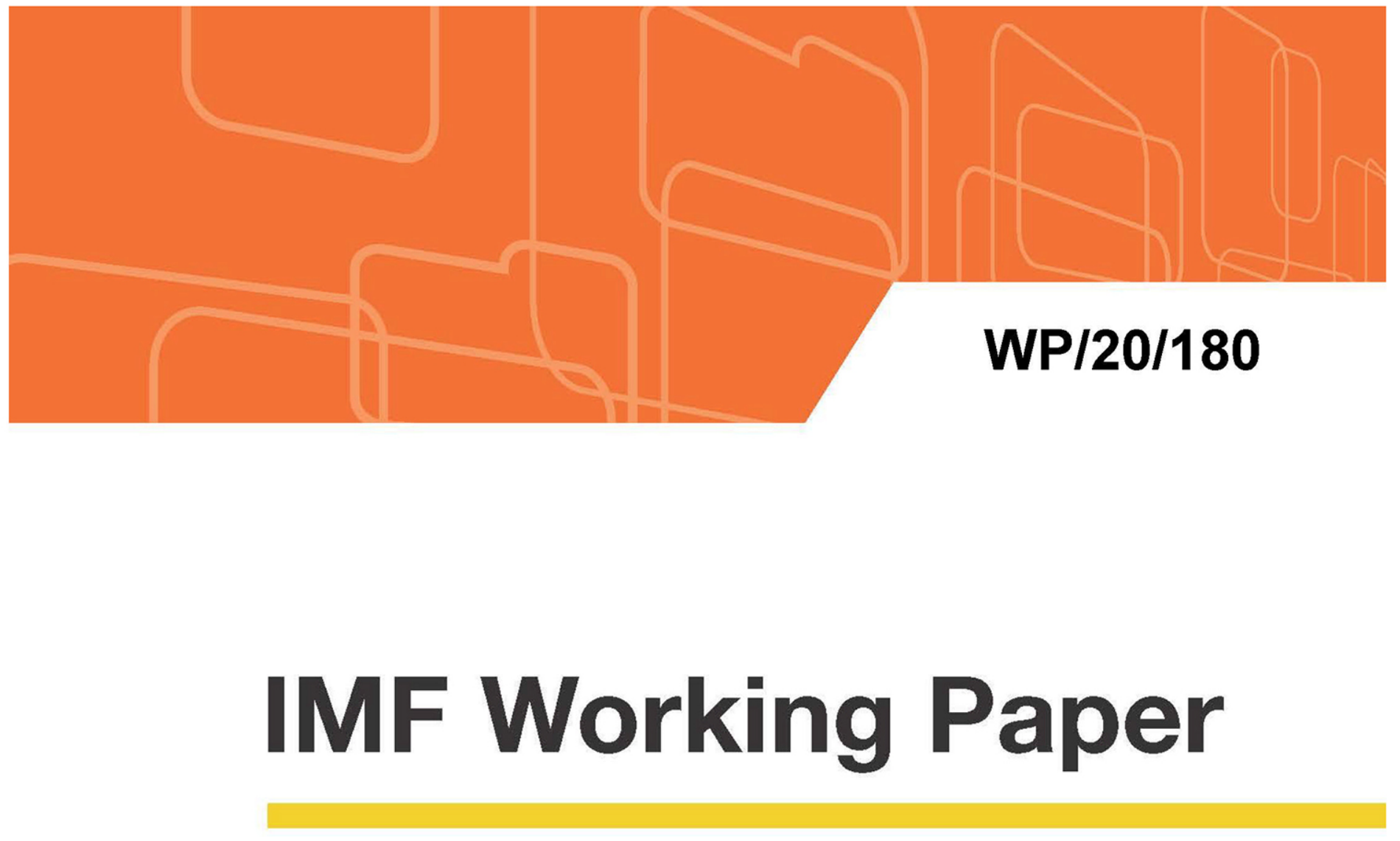

\title{
Monetary Policy Under an Exchange Rate Anchor
}

by Mariam El Hamiani Khatat, Mark Buessing-Loercks, and Vincent Fleuriet

IMF Working Papers describe research in progress by the author(s) and are published to elicit comments and to encourage debate. The views expressed in IMF Working Papers are those of the author(s) and do not necessarily represent the views of the IMF, its Executive Board, or IMF management.

$$
\text { I N T E R N A T I O N A L M O N E T A R Y F U N D }
$$




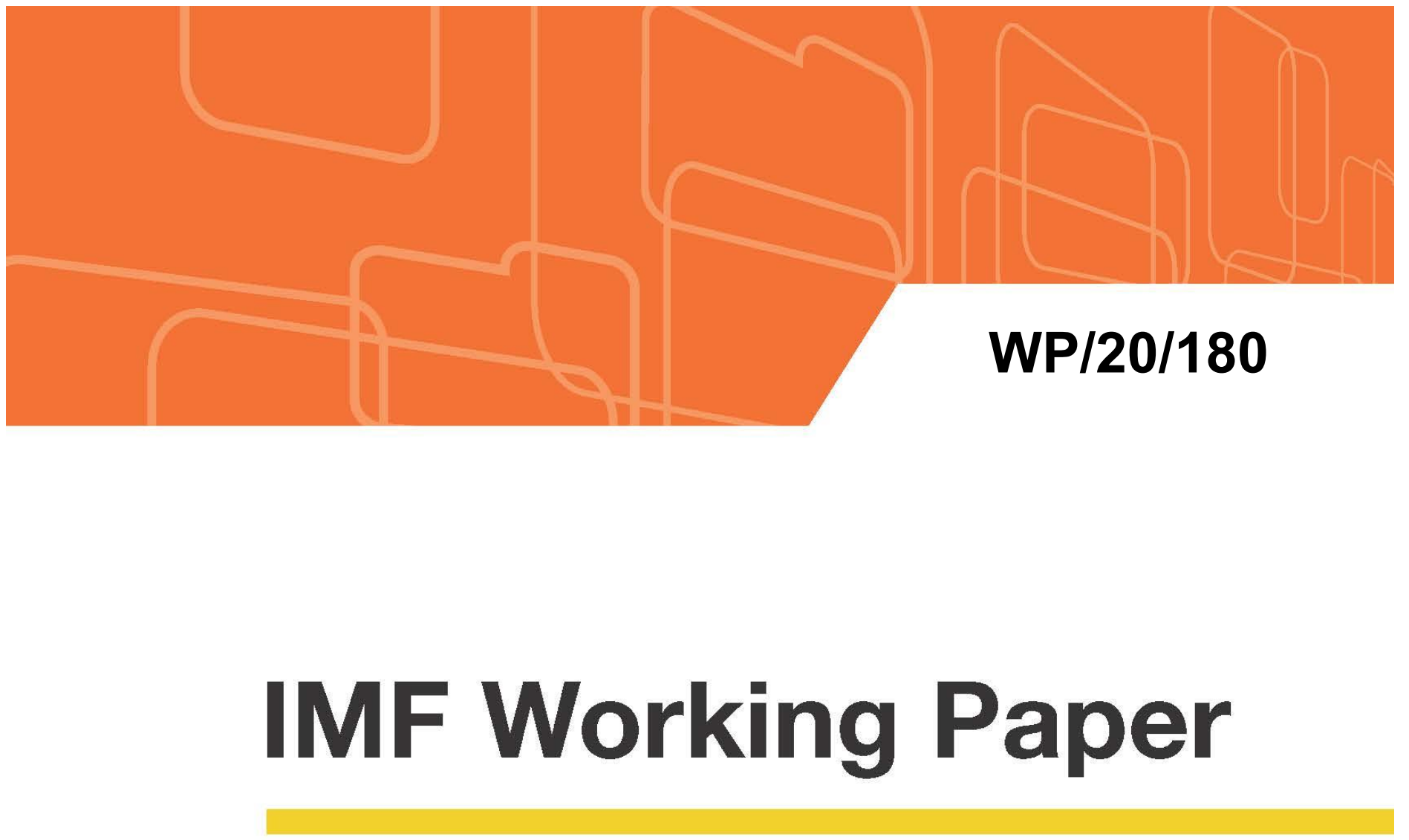

\section{Monetary Policy Under an Exchange Rate Anchor}

by Mariam El Hamiani Khatat, Mark Buessing-Loercks, and Vincent Fleuriet

IMF Working Papers describe research in progress by the author(s) and are published to elicit comments and to encourage debate. The views expressed in IMF Working Papers are those of the author(s) and do not necessarily represent the views of the IMF, its Executive Board, or IMF management.

$$
\text { I N T E R N A T | O N A L M O N E T A R Y F U N D }
$$




\title{
IMF Working Paper
}

Monetary and Capital Markets Department

Monetary Policy Under an Exchange Rate Anchor

\section{Prepared by Mariam El Hamiani Khatat, Mark Buessing-Loercks, and Vincent Fleuriet $^{1,2}$}

Authorized for distribution by Jihad Alwazir

September 2020

\section{IMF Working Papers describe research in progress by the author(s) and are published to elicit comments and to encourage debate. The views expressed in IMF Working Papers are those of the author(s) and do not necessarily represent the views of the IMF, its Executive Board, or IMF management.}

\begin{abstract}
This paper argues that there is scope for monetary policy under an exchange rate anchor, and discusses the related monetary policy design and implementation. It shows that the exchange rate can be used as the main monetary policy instrument while the policy rate can target the exchange rate. An exchange rate anchor is compatible with an inflation objective, provided fiscal dominance is not an issue, monetary conditions are supportive of the peg, and the level of international reserves is adequate. The paper argues that, while an exchange rate anchor is more prone to policy inconsistencies, there is ample scope for strengthening monetary policy design and implementation under soft pegs. In that context, the principles of dichotomy and interest rate parity are critical.

JEL Classification Numbers: E4, E5, E61, F31, F32

Keywords: monetary policy framework, exchange rate regime, interest rate parity, monetary policy rules, monetary operations, foreign exchange interventions

Authors' email addresses: melhamianikhatat@imf.org, mbuessing-loercks@imf.org, vincent.fleuriet@banque-france.fr.

\footnotetext{
${ }^{1}$ Vincent Fleuriet: Banque de France and previously IMF.

2 The authors would like to thank Jihad Alwazir, Bergljot Barkbu, Khalid Elfayoumi, Christopher Erceg, Olamide Harrison, Ashraf Khan, Darryl King, Bernard J. Laurens, Christoph Meyer, Dan Nyberg, Jochen Schmittmann, Miguel Segoviano, Ghiath Shabsigh, and Andreas Tudyka for their detailed comments and suggestions. The authors are also grateful to the Czech National Bank, the Danmarks Nationalbank, and the Monetary Authority of Singapore for their comments, corrections, and feedback.
} 


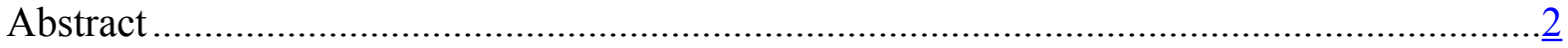

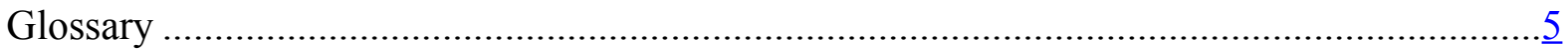

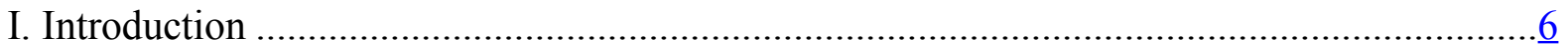

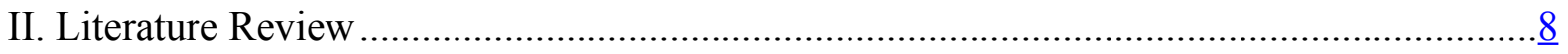

III. Selected Countries' Experiences..............................................................................11

A. The Danmarks Nationalbank Peg to the Euro.....................................................13

B. The Monetary Authority of Singapore's Exchange Rate-Based Monetary Policy .15

IV. The Exchange Rate as Main Monetary Policy Instrument ……........................................17

A. One Instrument, One Target..........................................................................17

B. One Anchor Currency Versus Multiple Currency Basket.......................................18

C. Multiple Supply and Demand Factors of Foreign Exchange ....................................18

D. Policy Inconsistencies and Their Consequences.....................................................19

V. The Monetary Policy Framework of Exchange Rate Targeters.......................................21

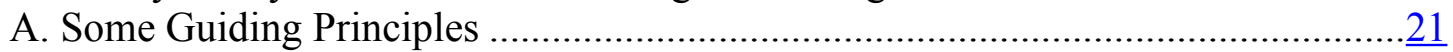

B. Lessons from Monetary Policy Transmission........................................................25

C. Central Bank Monetary Policy Rules.......................................................................

VI. Liquidity Management Under an Exchange Rate Anchor ................................................ 30

A. Introduction of an Interest Rate Corridor System ................................................

B. The Corridor Versus Floor System ………………........................................31

C. The Tiering Floor System Under an Exchange Rate Anchor....................................

VII. Transitioning the Exchange Rate Arrangement …………...............................................

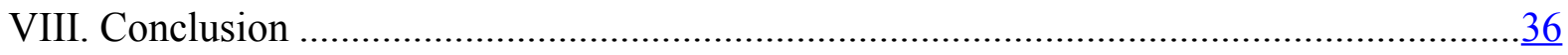

Figures

1. Capital Mobility, the Interest Rate-Exchange Rate Relation, and the Choice of Monetary

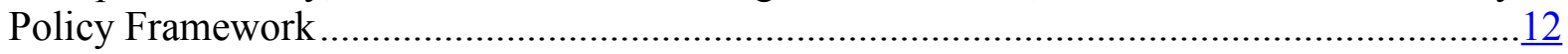

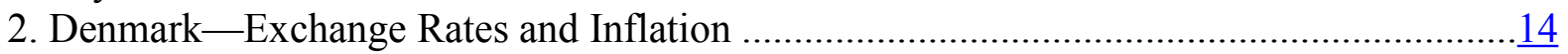

3. Denmark and Euro Area Policy Rates ……………......................................................14

4. Singapore - Inflation, Interest Rates, and Exchange Rates ............................................. 17

5. Selected Exchange Rate Targeters' Macroeconomic Indicators .........................................20

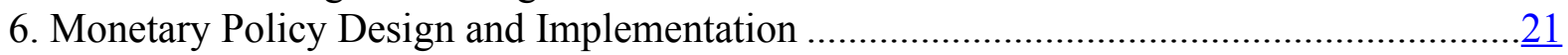

7. Monetary Policy Frameworks' Main Components .......................................................24

8. Monetary Policy Rules, Exchange Rate Arrangements, and Capital Account Openness ...229

9. Morocco Interest Rate Mid-Corridor System ...............................................................

10. Example of the Gradual Introduction of an Interest Rate Corridor ....................................

11. Danmarks Nationalbank Policy Rates and Liquidity Management Instruments ................. 
12. Moving Toward Greater Exchange Rate Flexibility-Transitional Exchange Rate Arrangements Adopted by Selected Countries...

\section{Appendixes}

I. Overview of Countries Adopting an Exchange Rate Anchor...

II. Monetary Policy Frameworks and Exchange Rate Arrangements of Countries Adopting an

Exchange Rate Anchor ......................................................................................................40

III. The Czech National Bank Exchange Rate Commitment...............................................41

IV. Main Supply and Demand Factors of Central Banks' Foreign Reserves...........................43

V. Countries Pegging or Stabilizing Their Exchange Rate and Anchor Countries' Inflation .44

References. 


\section{GLOSSARY}

AREAER Annual Report on Exchange Arrangements and Exchange Restrictions

CD Certificate of Deposit

CNB Czech National Bank

CPI Consumer Price Index

DNB Denmarks National bank

ECB European Central Bank

ELA Emergency Liquidity Assistance

EME Emerging Market Economy

ERR Exchange Rate Rule

FX Foreign Exchange

GCC Gulf Cooperation Council

GDP Gross Domestic Product

GFC Global Financial Crisis

IFS International Financial Statistics

IMF International Monetary Fund

IT Inflation Targeting

MAS Monetary Authority of Singapore

MoF Ministry of Finance

MQPM Moroccan Quarterly Projection Model

MT

Monetary Targeting

NEER Nominal Effective Exchange Rate

NFA Net Foreign Assets

OMO Open Market Operation

QPM Quarterly Projection Model

ToT Terms-of-Trade

TR Taylor Rule

UIP Uncovered Interest Rate Parity

WEO World Economic Outlook

YOY Year-on-Year 


\section{INTRODUCTION}

Countries de facto maintaining an exchange anchor ${ }^{3}$ represent $42 \%$ of those classified by the Annual Report on Exchange Arrangements and Exchange Restrictions (AREAER 2018), followed by other monetary policy frameworks (24\%), inflation targeters $(21 \%)$, and monetary targeters $(13 \%)^{4}$. Some exchange rate targeters are attempting to move toward further exchange rate flexibility, as other countries did previously, while others have preferred to settle in an exchange rate anchoring framework (for example, Denmark, Singapore, and the Gulf Cooperation Council (GCC) countries). For many exchange rate targeters, the overall monetary policy design and implementation is complicated, mainly due to the lack of clear guiding principles addressing the policy inconsistences that these countries face ${ }^{5}$. This paper focuses on monetary policy design and implementation of exchange rate targeters, based on the lessons learned from country experiences.

According to the Trilemma (Obstfeld and others 2004), countries cannot simultaneously fix their exchange rate, open their capital account, and conduct an independent monetary policy. However, in practice, many central banks with fixed exchange rates set the level of their policy rate even under capital mobility (El Hamiani Khatat and Veyrune 2019). Some countries also actively manage the exchange rate as a main monetary policy instrument, as evidenced by Singapore's monetary policy. As a matter of fact, the Trilemma doesn't explain how the interest rate-often considered the main instrument of monetary policy in current monetary policy frameworks - can be used to achieve a certain level of exchange rate rather than inflation, while the exchange rate can be the main monetary policy instrument stabilizing inflation. Fixing, stabilizing, or actively managing the exchange rate does not mean that monetary policy should be exclusively geared toward the exchange rate and that the central bank has to relinquish any management of short-term interest rates and banking system liquidity.

In particular, a central bank operating under capital mobility and a fixed exchange rate against a single currency can, for example, adopt a reaction function based on the principle of no large deviations from an interest rate parity condition. Under a credible peg, the local currency is not expected to change relative to the anchor currency; consequently, the local interest rate should normally equal the anchor country's interest rate adjusted with a risk

\footnotetext{
${ }^{3}$ According to the AREAER, an exchange rate anchor is a monetary policy framework where "The monetary authority buys or sells foreign exchange to maintain the exchange rate at its predetermined level or within a range. The exchange rate thus serves as the nominal anchor or intermediate target of monetary policy."

${ }^{4}$ Appendixes I and II.

${ }^{5}$ This paper focuses on soft pegs with adequate international reserves that it refers to as exchange rate targeters. According to the AREAER, soft pegs are conventional pegged arrangements, pegged exchange rates within horizontal bands, stabilized arrangements, crawling pegs, and crawl-like arrangements.
} 
premium $^{6}$. If there is an intended deviation from the interest rate parity condition, capital could, theoretically, flow to the highest interest rate-lowest risk country.

Monetary policy under an exchange rate anchor is, however, more complicated than a simple reaction according to a certain monetary policy rule: the policy needs not only to manage the interest rate differential and close the inflation gap with the anchor country(s). It also must take on board the level of international reserves that is considered adequate to support the credibility of the peg. Furthermore, monetary policy needs to address potential exchange rate misalignments that can arise from anticipated changes in anchor currencies, or imbalances in the money and foreign exchange (FX) markets.

Often the overall size of FX flows - related to current and capital account transactionsrather than the degree of openness of the capital account is the driver for arbitrage between the money and FX markets, in turn shaping the nature of monetary transmission. Exogenous shocks can be current account or capital account shocks, and a country can have an open capital account but no capital flowing in. On the other hand, even when the capital account is relatively closed, the ability of the central bank to target the interest rate to domestic conditions may be challenging, especially when FX reserves are low, and the economy is exposed to sizeable terms-of-trade (ToT) shocks.

This paper, which takes as a given the choice made by countries to adopt an exchange rate anchor, addresses the policy and operational challenges they may face, including: the need for supportive fiscal policy, strengthened and coherent monetary policy framework, the optimal choice of monetary policy rule, the coherent management of the interest rate and exchange rate, and choice of liquidity management framework. The rest of the paper is structured as follows: section II is a literature review; section III presents some country experiences with managing the interest rate and exchange rate under an exchange rate anchor; section IV discusses the use of the exchange rate as the main monetary policy instrument; section $\mathrm{V}$ presents additional guiding principles and different reaction functions that can help strengthen monetary policy design and implementation; section VI discusses specific liquidity management frameworks of some exchange rate targeters; section VII introduces evolving exchange rate arrangements; and section VIII concludes.

\footnotetext{
${ }^{6}$ The risk premium is a function of transaction costs, liquidity and credit risks, as well as the level of international reserves. According to Benlamine, Laxton, and others (2018), the risk premium is inversely related to the international reserve coverage ratio. This reflects the intuition that the more international reserves the central bank holds the more room for maneuver it has in defending the peg using direct interventions in the FX markets as opposed to policy rate adjustments.
} 


\section{Literature REVIEW}

Over the past 20 years, the literature has been prolific on topics related to inflation targeting (IT) including its variants - full-fledged IT, flexible IT, hybrid IT, IT-lite, inflation forecast targeting ${ }^{7}$ - and other related topics such as the pre-conditions for IT (Masson and others 1997, and Freedman and Ötker-Robe 2010) and the development of forecasting and policy analysis systems (Laxton and others 2009). The attention given to IT was driven by the desire to exit exchange rate and monetary targeting regimes. The economic literature has also extensively discussed the topic of optimal exchange rate regimes, at times calling for more flexible arrangements and describing country experiences with moving toward greater exchange rate flexibility (Ötker-Robe and others 2007). Economists and central bankers have also explored the topic of FX interventions, usually in the context of IT regimes (Ostry and others 2012). However, little has been written on the optimal management of interest rates and banking system liquidity under fixed or tightly managed exchange rates ${ }^{8}$. Yet central banks relying on the exchange rate as a nominal anchor also set the level of their policy rate and conduct liquidity management operations.

Four broad mainstreams comprise the literature on exchange rate targeting: (1) monetary dynamics under a fixed exchange rate; (2) optimal choice of exchange rate arrangement; (3) the transition from a fixed to a more flexible exchange rate; and (4) monetary policy rules of exchange rate targeters ${ }^{9}$.

\section{Optimal Choice of Exchange Rate Arrangement}

Following Mundell (1961) and the theory of optimal currency area, the optimal choice of an exchange rate arrangement depends on the nature of shocks - whether real or nominal — and the degree of capital mobility. In an open economy with capital mobility, the floating exchange rate insulates against real shocks (for example, ToT shocks), while a fixed exchange rate can be adopted in case of nominal shocks. The concept of optimal currency area is used in the academic literature both for setting the criteria for establishing a monetary union and the choice of exchange rate arrangement (Bordo 2003). The criteria suggested by Mundell (1961), McKinnon (1963), and Kenen (1969) to assess a region as an optimal currency area include the symmetry of shocks in member states, the degree of openness, the degree of labor mobility, and the ability to make fiscal transfers.

\footnotetext{
${ }^{7}$ Svensson (1997), Carare and Stone (2003), Stone (2003), Roger and others (2009), Clinton, Laxton and others (2015).

${ }^{8}$ In this paper, we define "banking system liquidity" as the sum of bank accounts in local currency at the central bank.

${ }^{9}$ See El Hamiani Khatat and Veyrune (2019) for monetary dynamics under fixed exchange rates.
} 
Other macroeconomic criteria relevant to the choice of exchange rate regime include the level of inflation, the level of international reserves, as well as fiscal policy flexibility and sustainability. Persistently high inflation can constrain the ability of a country to maintain an exchange rate peg against a low inflation anchor currency or basket of currencies. Without adequate international reserves, the monetary authorities may not be able to maintain an exchange rate peg. Since the exchange rate cannot be used as a shock absorber under a peg, fiscal flexibility is more important for fixed exchange arrangements (Eichengreen and others 1998). Fiscal policy sustainability is also critical for the viability of an exchange rate anchor, and the government debt-to-GDP ratio may be an indicator of vulnerability of a pegged exchange rate (Velasco 1996).

A distinct set of criteria underlying the choice of a fixed exchange rate arrangement is related to the importance of a credible nominal anchor. Credibly committing to low inflation policies may be challenging and costly in the absence of strong institutions, sound liquidity management, modeling and forecasting capabilities, and a stable financial system supporting interest rate transmission. Therefore, countries may also consider policy criteria rather than macroeconomic ones in their choice of an exchange rate arrangement. They may adopt pegs even when many of the macroeconomic criteria fail to apply, and when they choose to borrow the monetary policy credibility of another country or when the institutional capacity to implement flexible exchange rate regimes is still undeveloped (Levy-Yeyati and Struzenegger 2010, and El Hamiani Khatat and Veyrune 2019). According to Calvo and Mishkin (2003), the choice of exchange rate arrangement is likely to be of second order importance to the development of good fiscal, financial, and monetary institutions in producing macroeconomic success in emerging market countries.

\section{Transition from Fixed to more Flexible Exchange Rates}

In a world of increasing capital mobility, many countries choose to move away from fixed to more flexible exchange rate arrangements. The literature reveals that these countries are more likely to achieve a successful transition if they make the regime shift during periods of exchange rate appreciation. By contrast, the chances of a smooth transition are smaller in the presence of substantial depreciation pressures. The transition is also less disruptive when supported by monetary and fiscal policy tightening combined with strengthening monetary policy credibility and improving fiscal discipline. Sound monetary and fiscal policies are crucial for the proper functioning of any exchange rate arrangement, yet floating arrangements usually do not "break down" as fixed exchange rates (Eichengreen and others 1998).

When it comes to fixed exchange rate regimes, the literature highlights their vulnerability to currency crises (Bubula and Ötker-Robe 2003). Speculative attacks tended to occur following periods of expansionary monetary policies that led to higher inflation, overvaluation, and large external imbalances. While it may be possible to finance large current account deficits through the use of international reserves and capital inflows, these sources can be depleted 
over time. At some point capital flows will reverse direction, as they did during the global financial crisis (GFC), the taper tantrum, and the COVID-19 shock, forcing the move to greater exchange rate flexibility.

Ötker-Robe and other (2007) describes both orderly and disorderly cases of transition toward greater exchange rate flexibility. More recent IMF staff papers stress the need for transitional arrangements when considering the move to IT, but without specifically discussing the management of the interest rate, the choice of monetary policy rules, or the liquidity management frameworks under an exchange rate anchor. IMF (2015) addresses the case of countries that have regimes without an explicit commitment to a fixed exchange rate and with some degree of exchange rate flexibility, as the majority of low-and lower-middle income countries follows monetary targeting (MT) regimes. Laurens and others (2015) also focus on transitional arrangements for countries moving from MT to IT regimes.

In an MT regime, monetary policy implementation relies on the central bank's control over reserve money (Laurens and others 2015). However, under an exchange rate anchor, it can be challenging to implement a conventional MT regime as money is primarily endogenous. In addition, the monetary base can be composed mostly of items outside the direct control of the central bank - that is, autonomous liquidity factors such as the currency in circulation. Constraining the moves of the exchange rate results in positive liquidity shocks in times of FX reserves accumulation; in times of FX flow reversals and depending on each country's initial conditions, the central bank can decrease the reserve requirements, or increase its liquidity injections, or its policy rate. However, when the adverse exogenous shock is revealed to be more persistent than expected, the pressure on FX reserves, liquidity conditions, and the available eligible collateral may become unsustainable forcing the move to further exchange rate flexibility.

\section{Monetary Policy Rules of Exchange Rate Targeters}

Benlamine, Laxton and others (2018) propose a quarterly projection model (QPM) for Morocco that allows for a switch from a fixed to a flexible exchange rate regime. The differences between the two regimes are captured in exchange rate and interest rate equations (that is, an uncovered interest rate parity condition, UIP, and a Taylor Rule, TR). The authors, however, underscore the need for full reassessment and recalibration of the Moroccan QPM (MQPM) to reflect long-term modifications to agents' behavior under the planned flexible exchange rate regime.

Parrado (2004) identifies the monetary policy rule of the Monetary Authority of Singapore (MAS) as an exchange rate rule (ERR). The reaction function estimated by the author suggests that the policy of the MAS has a forward-looking orientation aimed at stabilizing both inflation and output. Singapore's monetary policy framework is centered on managing the exchange rate, with price stability as primary objective. 
Section V.C. provides a more detailed discussion on monetary policy rules under an exchange rate anchor. In this paper, we do not provide a detailed review of the extensive literature related to monetary policy rules; rather, we focus on the literature relevant to exchange rate targeters. Neither do we address the design of monetary policy rules that differs from one country to another; that is by itself a full area of research. Instead, we examine the current practices among exchange rate targeters in order to emphasize the principles of interest rate parity and dichotomy between policy decisions and implementation.

This paper adds to the previous literature by discussing monetary policy design and implementation of countries where MT is neither optimal-because of endogenous money and the absence of fiscal dominance - nor an interest rate-based monetary policy immediately feasible due to factors such as a muted interest rate pass-through to inflation. Properly managing the exchange rate when it is the only monetary policy instrument that the central bank can use to stabilize inflation may be a better option than leaving the monetary policy framework with no policy instrument or nominal anchor.

\section{SELECTEd COUNTRIES' EXPERIENCES}

We define an "interest rate-based monetary policy" as a regime where the interest rate is the main lever that the central bank uses to influence aggregate demand and inflation, as opposed to an "exchange rate-based monetary policy," where the main lever used to stabilize inflation is the exchange rate. Under an exchange rate-based monetary policy, the main monetary policy instrument is the exchange rate, and the management of the short-term interest rate is normally subordinate to the management of the exchange rate. In other words, the interest rate is set in a way that is consistent with or that supports or helps to achieve a certain level of the exchange rate (Figure 1). An exchange rate-based monetary policy is different from an interest rate-based monetary policy with FX interventions. Under an interest rate-based monetary policy with FX interventions, the main instrument used by the central bank to smooth out the business cycle and stabilize inflation is the interest rate, while FX interventions usually aim to dampen exchange rate volatility.

We review the experience of selected countries that adopted the exchange rate as a nominal anchor, with a focus on how they implemented it. The countries covered in this section are Denmark and Singapore. The case of the Czech National Bank (CNB) - that temporarily implemented an exchange rate floor within the context of a fully-fledged inflation targeting regime - is explained in appendix III. In contrast to Denmark and Singapore, the Czech Republic has conducted its monetary policy within the inflation targeting framework since 1998. The AREAER 2018 classifies the monetary policy framework of the Czech Republic

as IT and its exchange rate arrangement as floating. However, between November 2013 and April 2017, a floor on the koruna exchange rate was maintained as an exceptional tool to achieve further monetary policy easing in a situation when interest rates reached the lower bound. This extraordinary measure aimed at delivering the required monetary policy stance 
to prevent the deflation threat ${ }^{10}$. After the introduction of the floor, the AREAER 2014 classified the exchange rate arrangement of the Czech Republic as "other managed arrangement", and one year later as a "stabilized arrangement"; the monetary policy framework of the Czech Republic remained classified as IT.

Figure 1. Capital Mobility, the Interest Rate-Exchange Rate Relation, and the Choice of Monetary Policy Framework

\subsection{CAPITAL Mobility/Large FX Flows}

Interest rate-based monetary policy

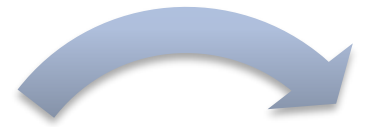

\section{CB with interest} rate-based monetary policy

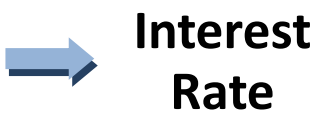

Exchange Rate

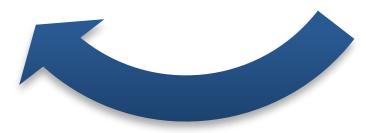

Exchange rate-based monetary policy

1.2. CAPital Controls/Shallow FX Flows

\section{Central}

Bank
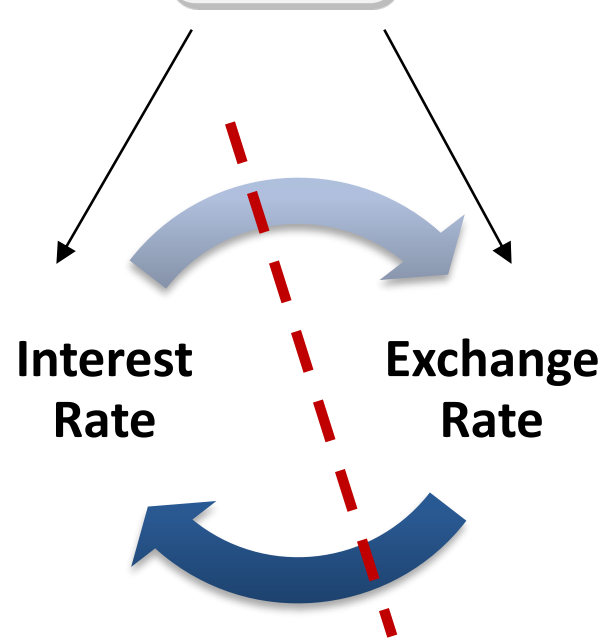

Source: the authors.

\footnotetext{
${ }^{10}$ For more details, see Franta and others (2014).
} 


\section{A. The Danmarks Nationalbank Peg to the Euro}

Denmark has pursued a fixed exchange rate policy since the early 1980s, first against the D-

mark and since 1999 against the euro. Since then, Denmark has maintained a fixed exchange rate vis-à-vis the euro and has participated in the European Exchange Rate Mechanism at a central rate of 746.038 krone per 100 euro, with a narrowed fluctuation band of $+/-2.25$ percent $^{11}$. The exchange rate regime provides a framework for low and stable inflation in Denmark (Figure 2). Within this framework, the DNB policy rates are geared to the management of the exchange rate and cannot be used for the management of the business cycle. The DNB's liquidity management, in turn, focuses on the management of the size of bank accounts to ensure the sufficiency of liquidity in the banking system in support of money market and payment system functioning, as well as financial stability.

When there are no pressures in the FX market, the DNB usually changes its interest rates in step with the ECB's (European Central Bank) policy interest rates (Figure 3). In case of short-term fluctuations in the exchange rate, the DNB influences the exchange rate of the krone by intervening directly in the FX market. However, when FX interventions are deemed insufficient to stabilize the exchange rate, the DNB may adjust the policy rate spread vis-àvis the euro area to impact capital flows. Following the GFC in October 2008, the DNB increased the policy rate spread and sold FX reserves due to heightened uncertainty and exchange rate pressure. In 2009, the DNB gradually reduced the policy rate spread and accumulated FX reserves.

\footnotetext{
${ }^{11}$ Until very recently, the Danish kroner has been the only ERM II participant; the Bulgarian lev and the Croatian kuna joined ERM II on July 13, 2020. ERM II was set up in 1999 also to help non euro-area countries prepare themselves for participation in the euro area. Countries such as Cyprus, Estonia, Greece, Latvia, Lithuania, Malta, Slovakia, and Slovenia have since then left ERM II and joined the eurozone. Whereas currencies in Malta, Estonia, Lithuania, and Latvia had been pegged to the euro before joining the eurozone, currencies in Cyprus, Greece, Slovenia and Slovakia were free floating. These currencies thus transitioned from a free-floating currency towards a peg ahead of the adoption of the euro.
} 
Figure 2. Denmark-Exchange Rates and Inflation

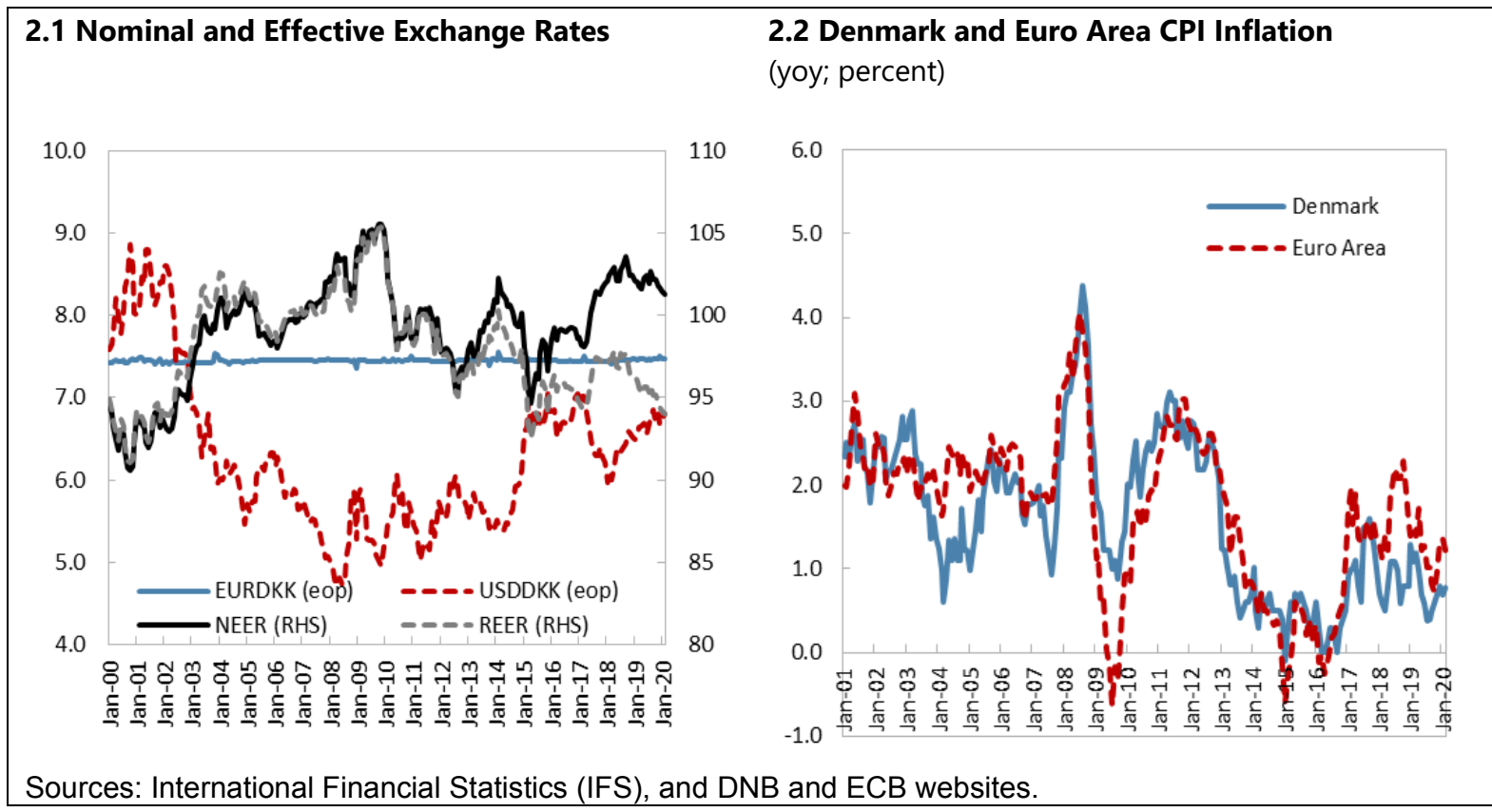

In early 2015, the Danish economy witnessed massive capital inflows, and appreciation pressure on the exchange rate, following Switzerland's abandonment of its quasi-peg. This event triggered speculation against the Danish fixed exchange rate, prompting the DNB to intervene substantively in January and February 2015. At that time, the DNB abstained from further interest rate reductions, given the already low policy rate (deposit rate reduced to -0.75 percent) and negative policy rate spread. Between April 25 and September 4, 2014, the DNB Figure 3. Denmark and Euro Area Policy Rates temporarily moved the interest rate of its certificates of deposits (CDs) to positive levels ${ }^{12}$ before starting a reduction cycle of their interest rate, pushing them further negative, reaching a level of -0.75 percent on February 6, 2015.

\footnotetext{
${ }^{12}$ DNB press releases of April 24, 2014 and September 4, 2014.
} 


\section{B. The Monetary Authority of Singapore's Exchange Rate-Based Monetary Policy}

Singapore's monetary policy has price stability as its primary overreaching objective, and the exchange rate as the monetary policy anchor. The MAS is explicit about its exchange ratebased monetary policy and does not target a level of domestic interest rates. The MAS manages the Singapore dollar against a trade-weighted basket of currencies of Singapore's major trading partners that it maintains within a target band. The composition of the basket is revised periodically to reflect the changes in trade patterns over time. Whenever necessary, the MAS intervenes in the FX market to maintain the nominal effective exchange rate (NEER) within the policy band. Overall, the MAS's exchange rate-based monetary policy framework is characterized by three main features:

1. The basket: the currencies forming the basket are assigned different weights depending on Singapore's trade share with each country.

2. The policy band: the NEER can fluctuate within a policy band, the level and slope of which are announced semi-annually to the market. The band provides a mechanism to accommodate short-term fluctuations in the FX markets.

3. The crawl: the policy band is periodically reviewed to ensure that it remains consistent with the underlying fundamentals of the economy. The band incorporates a crawl feature reflecting the continuous assessment of the path of the exchange rate, to avoid any misalignment of the currency.

By announcing a targeted path for the NEER, whose composition is undisclosed, the MAS signals the policy stance that is deemed appropriate to fulfill its price stability mandate. This path respects the underlying fundamentals of the economy. Recognizing the lags in monetary policy, the MAS gauges the appropriate policy stance and operates in a forward-looking manner by considering trends and anticipated developments in the domestic economy and external environment ${ }^{13}$.

The MAS monetary policy framework ensures a clear separation between policy formulation and implementation. Its Economic Policy Group reviews the monetary policy semi-annually and recommends the appropriate level, slope, and width for the exchange rate policy band to ensure its consistency with the fundamentals and market conditions. After each review, a monetary policy statement is released, providing information on the latest movements of the exchange rate and explaining the exchange rate policy stance going forward. An accompanying report, the Macroeconomic Review, provides detailed information on the assessment of macroeconomic developments and trends in the Singapore economy.

\footnotetext{
${ }^{13}$ Parrado (2004).
} 
In its monetary policy communications, the MAS makes qualitative clarification on the parameters of the Band Basket and Crawl (BBC) framework. Unlike a central bank that uses the policy interest rate as a tool, the MAS does not disclose the numerical values of the BBC parameters and/or their changes. For example, the January 2015 interim monetary policy statement said that "the slope of the policy band will be reduced". However, in the April 2016 statement, the MAS announced a zero rate of appreciation for the policy band, which was further clarified in the October 2016 statement, for example, as to be maintained for an "extended period." The MAS publishes the prevailing level of the weekly NEER with a lag of about a month ${ }^{14}$.

At the operational level, the MAS FX interventions are triggered by one of two main factors: (1) the NEER reaches the edge of the policy band on either side; or (2) there is undue volatility or speculation against the currency. The MAS may also intervene before the band is reached or allow the NEER to breach the band before intervening, but refrains, as much as possible, from intervening unnecessarily and allows market forces to determine the level of the Singapore dollar exchange rate within the policy band.

The MAS's liquidity management framework aims mainly to ensure that there is a sufficient but not excessive amount of liquidity in the banking system, that is, that meets banks' demand for precautionary and settlement balances. The MAS conducts daily liquidity management operations guided by autonomous liquidity factors forecasts, and exclusively with primary dealers. The liquidity management operations include: (1) direct borrowing or lending; (2) FX swaps; (3) repurchase agreements (repos); and (4) MAS bills. The MAS also operates a standing facility, a two-sided discount window that allows real time gross settlement system participants to deposit Singapore dollar funds with or borrow Singapore dollar funds against eligible collateral from the MAS on an overnight basis. The borrowing and lending rates for the standing facility are market-determined (Figure 4).

Depending on the macrofinancial conditions, the MAS supplies more or less liquidity than required to meet banks' needs. For example, in mid-September 1985, when there was a speculative attack against the Singapore dollar, the MAS intervened in the FX market to sell US dollars but did not offset the liquidity drain of its FX interventions through liquidity management operations: the intervention was left unsterilized to maintain banking system liquidity in line with autonomous factor developments. At the onset of the GFC in 2007, the MAS left more liquidity in the domestic banking system to alleviate tightness in funding markets, and subsequently withdrew some of the excess in 2011-12, when financial markets stabilized ${ }^{15}$.

\footnotetext{
${ }^{14}$ IMF (2018).

${ }^{15}$ MAS (2013).
} 
Figure 4. Singapore-Inflation, Interest Rates, and Exchange Rates

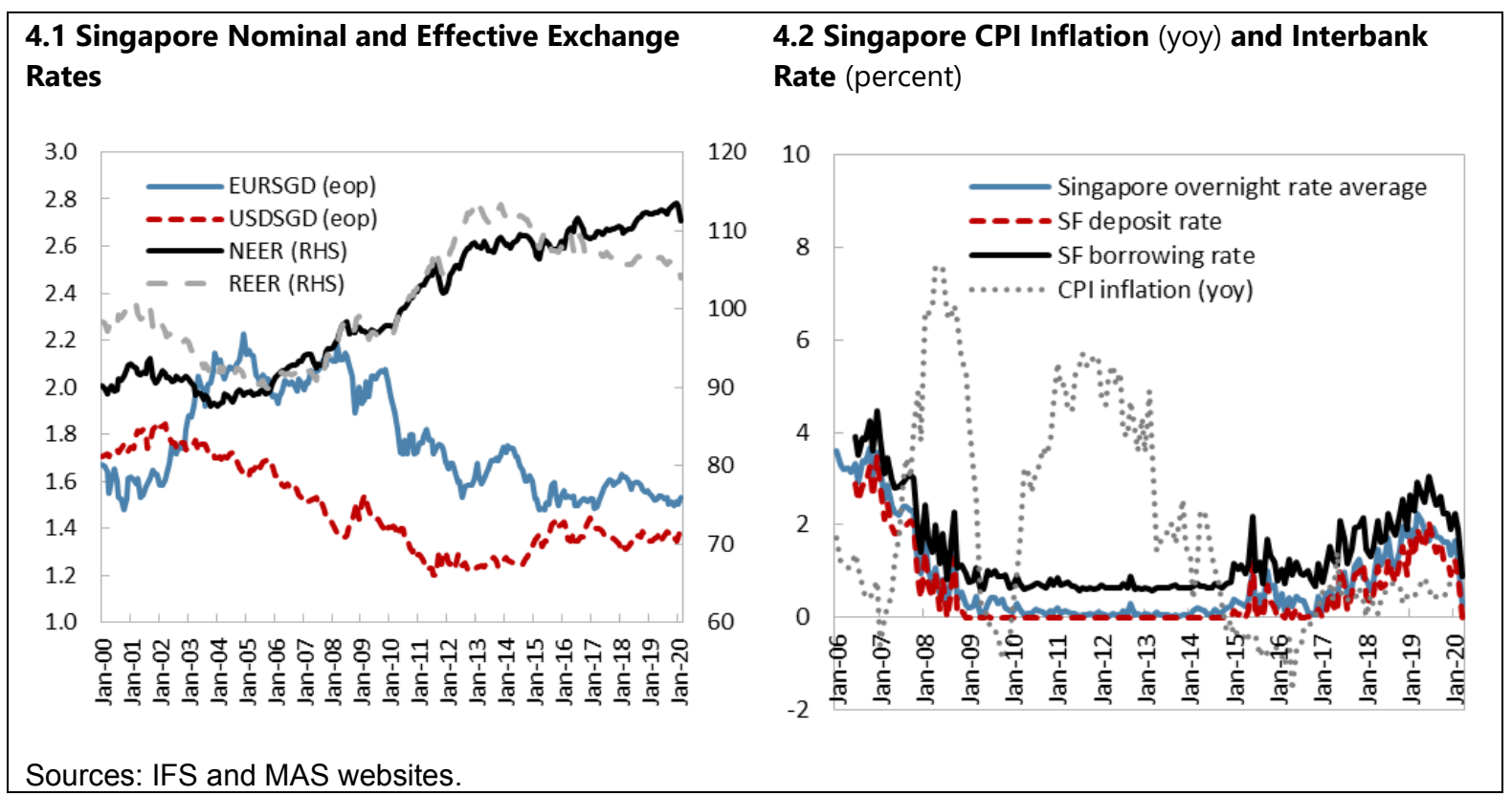

IV. The Exchange Rate as Main Monetary Policy Instrument

\section{A. One Instrument, One Target}

Beyond the widespread fear of floating (Calvo and Reinhart 2000), countries peg or tightly manage their exchange rate for a number of reasons: to accumulate FX reserves, preserve competitiveness, and curtail inflationary pressures in the absence of an alternative nominal anchor. Some countries attach their exchange rate to that of a larger economy because its macroeconomic developments drive those of the exchange rate targeter. Where the financial sector is heavily dollarized, countries have also leaned against currency depreciation for financial stability concerns. The exchange rate typically plays a dominant role in developing and emerging market economies than in advanced economies, where most domestic and foreign transactions are in local currency, markets are deeper, and the private sector is better prepared to cope with FX risk. Pass-through from the exchange rate to inflation is typically higher in developing and emerging market economies ${ }^{16}$.

Managing the exchange rate can be achieved through discretionary or rule-based FX interventions, or through the use of the policy rate to influence the exchange rate. In the latter case, the use of the interest rate reduces the need for sizeable FX interventions, thus preserving FX reserves. Fully discretionary monetary and exchange rate policies allow maximum flexibility in responding to unexpected shocks but may result in conflicting signals about the central bank's objectives, thus undermining monetary policy credibility (Ostry and

${ }^{16}$ Ostry and others (2012). 
others 2012). Full discretion also risks misusing the exchange rate for objectives other than inflation (for example, competitiveness, financial stability), and may increase the risk of asymmetrical or one-sided FX interventions. When the exchange rate is the main monetary policy instrument, its role and objective in the overall monetary policy framework should be clearly explained and communicated to the public.

\section{B. One Anchor Currency Versus Multiple Currency Basket}

Anchoring the domestic currency to a basket of currencies reduces the risk of misalignment in particular when major changes of the single anchor currency are expected. A country with diversified trade that anchors its exchange rate to a single currency—or to a basket of currencies with a dominant weight of one specific currency - is more affected by the fluctuations of this dominant anchor currency that can disrupt its macroeconomic balance. In addition, changes in bilateral rates create a certain level of FX risk and incentivize market participants to better hedge against currency risks as well as the growing use and development of hedging instruments.

Yet, distortions can arise when the exchange rate is rigidly fixed against an unchanged basket of currencies. This can be the case when the moves of the anchor currencies are inconsistent with the fundamentals, or conversely, when the basket is too stable while the economy faces sizeable exogenous shocks. When the anchor currencies are on an appreciating trend, a resulting loss in competitiveness can occur. For example, in the early 1980s, the US dollar appreciated significantly while the Singapore dollar was tracking the US dollar more closely than other major currencies. This resulted in a loss of competitiveness of Singapore-based companies relative to those in countries whose currencies weakened against the US dollar ${ }^{17}$.

\section{Multiple Supply and Demand Factors of Foreign Exchange ${ }^{18}$}

For many exchange rate targeters with shallow financial markets, the main supply and demand factors of FX are related to trade balance transactions and remittances. However, these flows do not necessarily translate to flows with the central bank. In practice, a large part of these flows can remain within firms, households, and eventually commercial banks. Depending on their own anticipation of future exchange rate moves, the surrender requirements, and the exchange rate arrangement in place, commercial banks may sell more or less FX holdings to the central bank. Typically, if economic agents expect a depreciation of the local currency, they will retain larger amounts of FX. Some economic agents can even start buying more FX from the central bank than needed (when permitted) in case of depreciation expectations. In some cases, such situations could even lead to a dollarization of the economy, especially when the credibility of the monetary policy framework and

\footnotetext{
${ }^{17} \operatorname{MAS}(2001)$.

${ }^{18}$ The main factors are described in appendix III.
} 
exchange rate arrangement is weak. Depreciation expectations triggered by current account imbalances may be magnified by loose monetary conditions, weak liquidity management, and inadequate FX reserves' level and management policies.

When financial markets are more developed, and in the absence of capital controls, banks and/or their clients may arbitrate the FX and capital markets of the anchor countries against the local country, under the covered interest rate arbitrage. This arbitrage also takes into account the credit risk of the investments. During the euro area sovereign crises, many investors decided to reinvest some of their liquidities in countries with less credit risk, such as Denmark or Switzerland. To reduce this appetite for Danish and Swiss assets, the two central banks decreased their policy rate, since in these countries the policy rate has a strong impact on the demand and supply of FX, and eventually on the exchange rate itself.

\section{Policy Inconsistencies and Their Consequences}

There are different types of policy inconsistencies that can emerge under an exchange rate anchor. In this section, we identify and discuss three of them: (1) the inconsistency between the management of banking system liquidity and the exchange rate; (2) between the anchor currency movements and balance of payment developments; and (3) between fiscal policy and the exchange rate arrangement. In addition, the coherent management of the interest rate and the exchange is discussed in several sections and is one focus of this paper.

Quantitative measures can have destabilizing effects on the exchange rate when the latter is the monetary policy anchor. When the exchange rate is flexible, quantitative measures depreciate the exchange rate. However, when the exchange rate is fixed or tightly managed, a significant liquidity injection by the central bank can increase the demand for FX and lead to pressures on international reserves. This may ultimately weaken the sustainability of the exchange rate anchor. Unsterilized liquidity surpluses can also destabilize the equilibrium on the money and FX markets and stimulate the demand for FX and speculation rather than the supply of domestic credit.

As suggested earlier, a currency pegged against the US dollar will follow an appreciation path when the US dollar is appreciating (and conversely). This mechanical appreciation can be inconsistent with the economic fundamentals if the country that is pegging its currency against the US dollar is facing an adverse current account shock at the same time. Hence rigidly managed exchange rates can become sources of imbalances and distortions in times of anchor currencies' instability. Further, when the anchor currency displays a clear depreciation path, such as the US dollar in the aftermath of the GFC (2007-08) and the euro during the euro area crisis (2011), the local currency of the exchange rate targeter becomes more prone to speculation, complicating liquidity management by the central bank.

Monetary policy under an exchange rate anchor requires fiscal discipline to prevent current account imbalances and the resulting pressures on international reserves. In case of fiscal dominance, it is more likely that the exchange rate anchor will become unsustainable. As 
shown by country experiences, the success of an exchange rate anchor owes much to the strong economic fundamentals of the countries that were able to implement and maintain credible exchange rate anchors (Figures 5).

Figure 5. Selected Exchange Rate Targeters' Macroeconomic Indicators
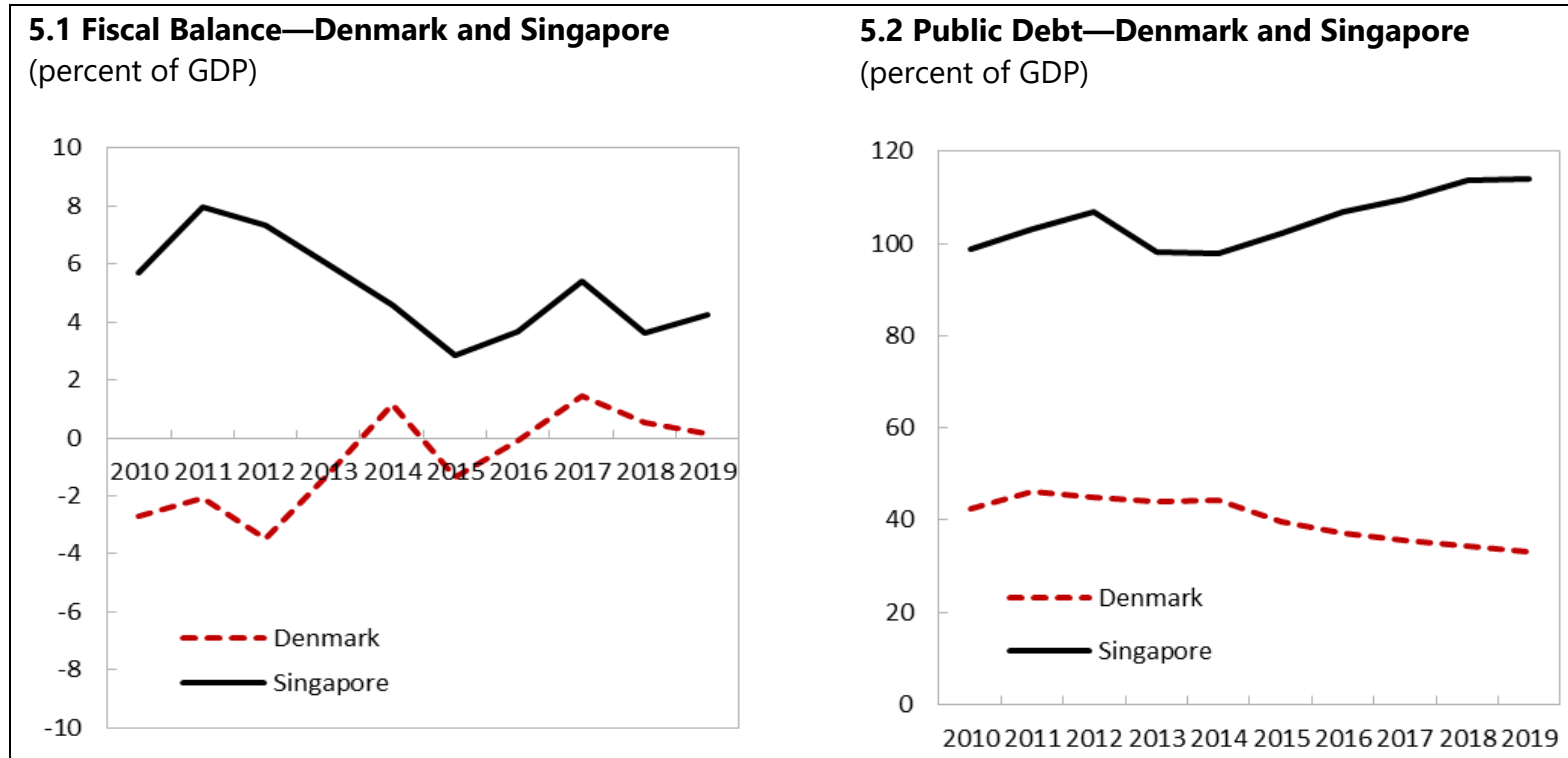

\subsection{Current Account Balance-Denmark and Singapore} (percent of GDP)

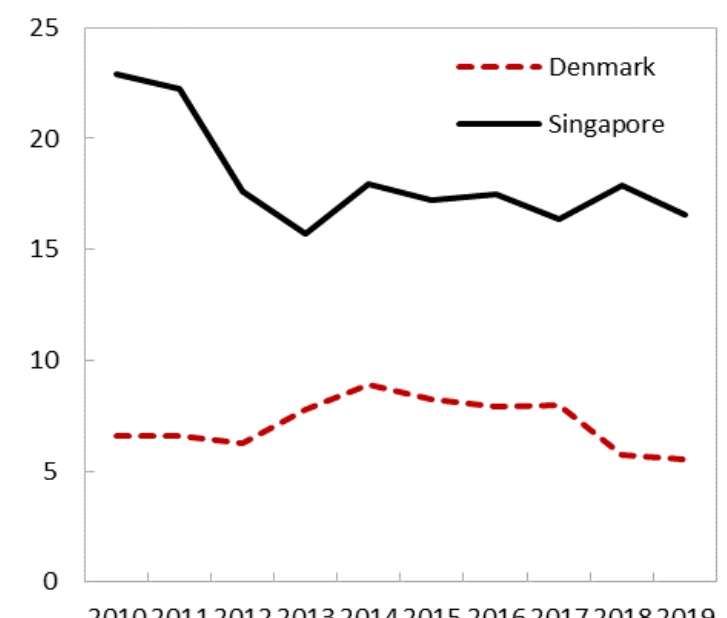

\subsection{Annual CPI Inflation-Denmark and Singapore (percent of GDP)}

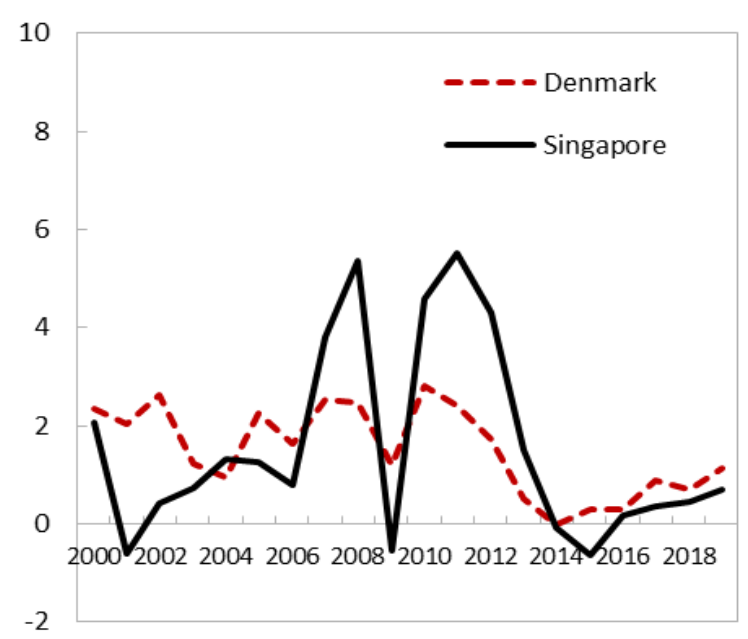

Note: The Singapore Government does not borrow to fund its budget. Government debt is issued to deepen the domestic market, to meet the investment needs of the Central Provident Fund, and to provide individuals a longterm savings' option. All borrowing proceeds from the bond issuance are invested.

Sources: IMF World Economic Outlook (WEO) database and IFS. 
The necessity to address these potential inconsistencies confronts exchange rate targeters with specific challenges and calls for specific recommendations for countries maintaining fixed or tightly managed exchange rates. These principles are developed in the following section.

\section{The Monetary Policy Framework of Exchange Rate Targeters}

\section{A. Some Guiding Principles}

Sound monetary policy design and implementation usually involves the following six processes (Figure 6):

\section{Choice of the monetary policy}

framework. The choice of the most appropriate monetary policy framework, while country specific, is not arbitrary. It depends on: (1) the level of international reserves, and pressures on the external accounts; (2) the composition of reserve money and structural liquidity position of the banking system; (3) the soundness and level of development of the financial sector including its institutions and markets and its overall ability to transmit the monetary policy stance to the real economy; (4) the nature of fiscal financing, fiscal dominance risks, and their implications for banking system liquidity and government bond market development; and (5) the

Figure 6. Monetary Policy Design and Implementation

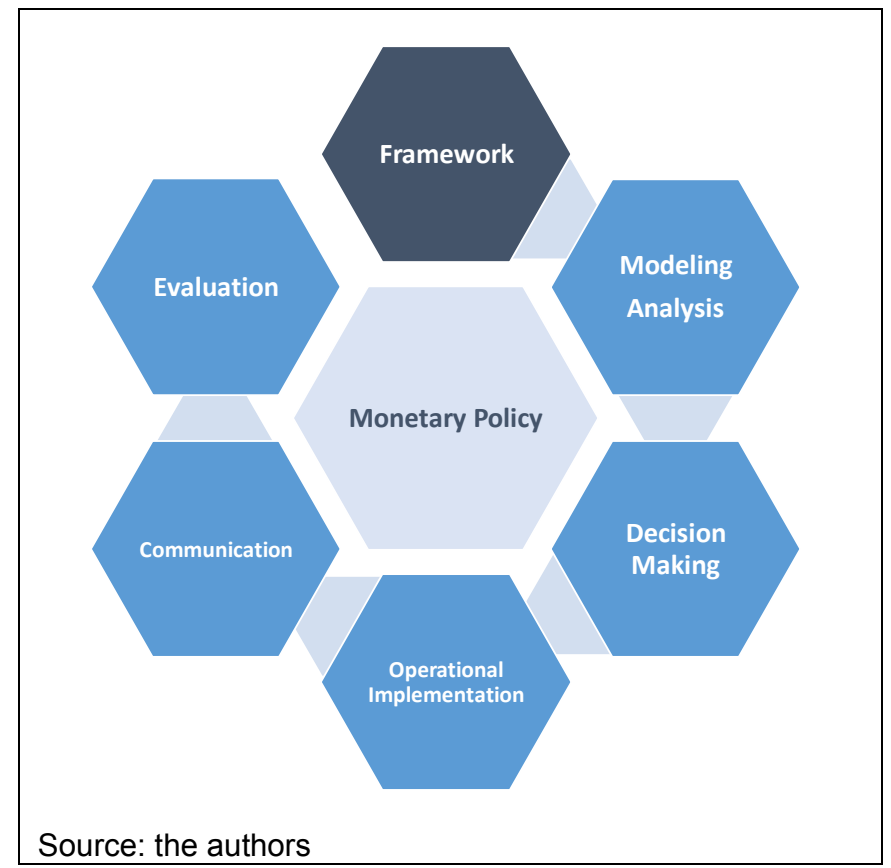
central bank governance, mandate, decision-making process and capacity. Beyond the need to ensure its independence (institutional, financial, and organizational), the central bank's technical and analytical capacities are critical for the choice of the monetary policy framework.

2. The monetary, macroeconomic, and financial analysis needed to support the monetary policy decision making process. Regardless of the nominal anchor in place, the central bank needs to conduct thorough analysis of the macro-financial environment under which it designs and implements monetary policy. It should also have a clear understanding of inflation and exchange rate expectations of economic agents. The central bank needs to make decisions on its policy rate, exchange rate, or reserve money and should develop its analytical and modeling capacities and produce reliable macroeconomic and inflation forecasts. 
3. Decision-making process of monetary policy. The decision-making process involves several committees and entities within the central bank, as well as the internal and external communication needed to announce the decisions, underlying assumptions, scenarios, and risk factors.

4. Operational implementation of monetary policy, which consists of (1) designing the liquidity management operations needed to align a short-term money market rate (secured or unsecured) with the policy rate or to maintain bank reserves consistent with the reserve money path; and (2) calibrating the volume of monetary operations to achieve the operational target of monetary policy. In addition, for exchange rate targeters, the operational implementation includes FX interventions conducted to fix, stabilize, or manage the exchange rate.

5. Communication of monetary policy decisions needed to anchor inflation expectations and market expectations. Under an interest rate-based or an exchange rate-based monetary policy, sound central bank communication is needed as the bank has considerable impact not only on inflation expectations of economic agents but also on exchange rate developments, FX markets and market participants' behavior and decisions.

6. Finally, the evaluation of monetary policy to assess the suitability of the decisions made and eventually the overall monetary policy framework.

Adopting a framework where inflation is the ultimate monetary policy objective, as well as a forward-looking approach to monetary policy, is not incompatible with an exchange rate anchor as long as banking system liquidity, the interest rate, and the exchange rate are managed properly and coherently. An exchange rate-based monetary policy also presupposes that the central bank has the capacity to develop the liquidity forecasting and management frameworks, as well as the appropriate macro-economic modeling and forecasting tools.

Building on the international experience and the literature reviewed, we identify a set of institutional building blocks and guiding principles for the conduct of monetary policy under an exchange rate anchor.

\section{Institutional prerequisites}

1. The FX policy and its operational implementation should be one of the core mandates of the central bank and clearly specified in its law. Leaving the management of the exchange rate fully or partially to the fiscal authority means constraining the central bank's ability in fulfilling its ultimate inflation objective, as well as its flexibility in using its main monetary policy instrument. Even when coordination between the monetary and fiscal authorities is efficient, political considerations may restrict or delay important and timely exchange rate decisions. 
2. Fiscal policy should be supportive to avoid threatening the sustainability of the overall framework. Sound and credible macroeconomic policies have proven essential in avoiding the build-up of large external imbalances and in minimizing vulnerability to pronounced swings in capital flows. Current account and fiscal surpluses are important for the viability of an exchange rate anchor, as they support an appreciation trend of the currency and FX reserves accumulation.

\section{Guiding principles for monetary policy design and implementation with an exchange rate anchor}

1. The exchange rate should preferably target one main objective: inflation. Within this framework, the central bank should prepare for the more active and forward-looking management of the exchange rate. Such preparation includes strengthening the central bank's (1) ability to assess exchange rate misalignments; (2) modeling and macroeconomic forecasting capacity to implement a forward-looking monetary policy; and (3) monitoring and management of banking system liquidity.

2. Price stability (inflation) is the ultimate objective of the exchange rate targeter while the exchange rate is the nominal anchor and the main monetary policy instrument. Adopting an exchange rate anchor is not incompatible with stable inflation and does not necessarily result in inconsistent policies and/or objectives when the exchange rate, the interest rate, and banking system liquidity are managed coherently. This is because inflation and the exchange rate are assigned different roles in the monetary policy framework (Figure 7).

3. An assessment of monetary transmission and inflation determinants should precede the choice of the monetary policy rule and should guide monetary policy decisions. The reaction function of the central bank should reflect the results and lessons extracted from this empirical assessment rather than link the policy rate to an inflation target when the empirical evidence does not support such a link. The determinants of inflation should be identified and serve as a basis for specifying the reaction function.

\section{The processes of setting or changing the level of the policy rate and stabilizing money} market rate fluctuations are two distinct processes. Stabilizing short-term fluctuations of money market rates is an operational fine-tuning process that is often separated from setting or changing the level of the policy rate. The level of the policy rate is usually decided by the central bank board or monetary policy committee (MPC) according to a policy rule embedded in a core projection model, supported by a suite of other forecasting models and tools.

5. The interest rate should be managed coherently with the exchange rate. The policy rate can have a different role in the monetary policy framework of exchange rate targeters than the commonly admitted role of stabilizing inflation and output around its potential. Therefore, the monetary policy rule under an exchange rate anchor can be different than a standard forward-looking TR. 
6. Liquidity management retains the important role of stabilizing money market rates and anchoring the short end of the yield curve. The liquidity management framework should aim at preventing persistent and large liquidity surpluses, and at avoiding quantitative measures or over-injection of central bank liquidity when these may potentially destabilize the exchange rate.

7. Central bank communication should be handled carefully and focus on market considerations beyond the macroeconomic conditions, so as to prevent unnecessary market volatility. Greater transparency is important in fostering market discipline, and in reducing the likelihood of market overreaction as a result of a lack of information or information asymmetries ${ }^{19}$. Although clear communication is helpful at the strategic level, there is a limit to transparency at the operational level of policy implementation. The FX policy and objectives sought by the FX intervention should be transparent; however, it is important to note that many central banks retain some form of ex-ante secrecy around their FX interventions.

Figure 7. Monetary Policy Frameworks' Main Components

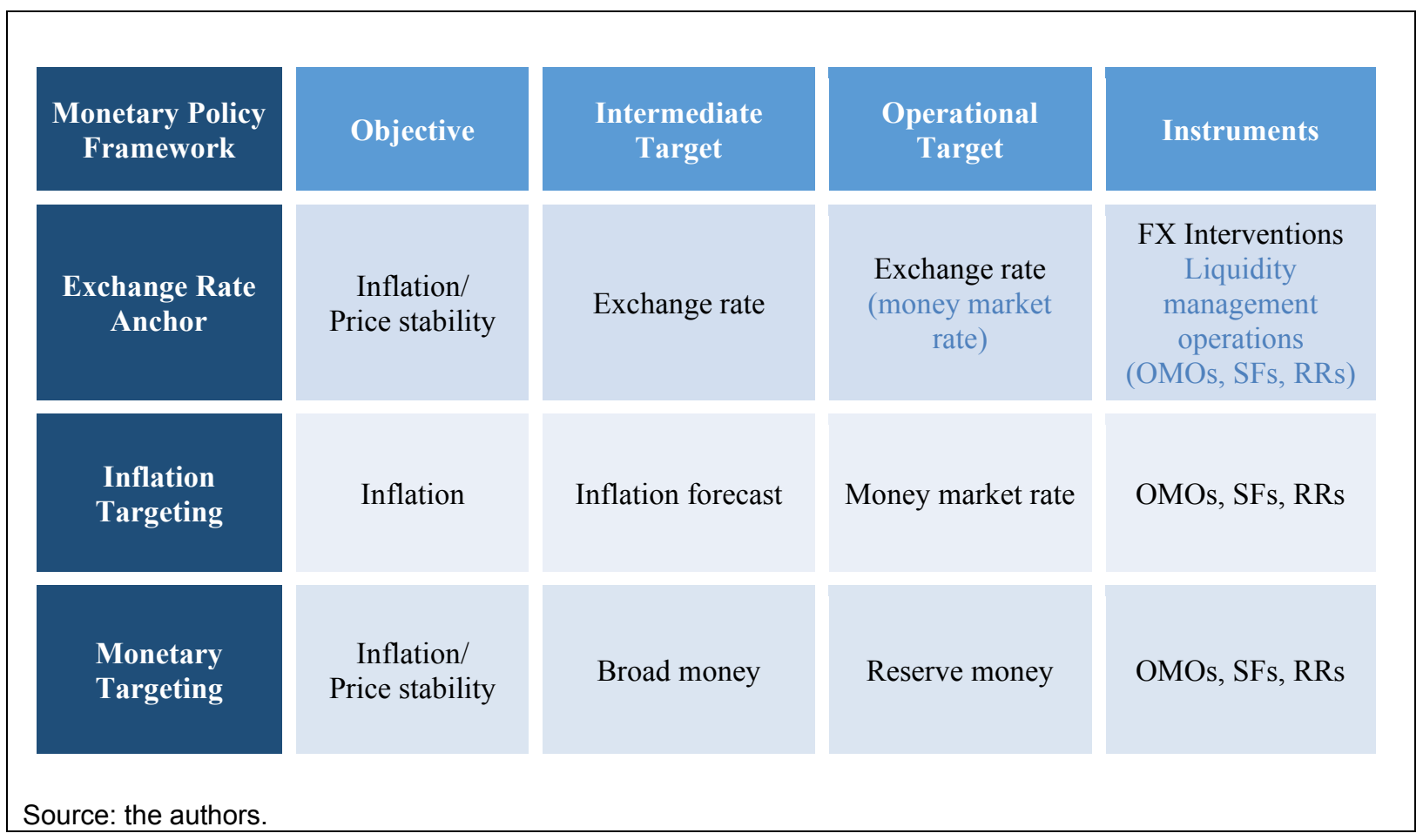

${ }^{19} \operatorname{MAS}(2004)$. 


\section{B. Lessons from Monetary Policy Transmission}

Under the standard macroeconomic view, the interest rate channel is the main channel of monetary transmission, and an expansionary monetary policy decreases short-term interest rates, depreciates the exchange rate, and stimulates aggregate demand. However, central banks operating exchange rate anchors do not always have an effective control over liquidity conditions and short-term interest rates. Some of these central banks can be tempted to leave the liquidity surpluses - generated by their FX interventions - unsterilized, or to sterilize the excess at very low interest rates. Further, central banks of developing or emerging market economies often engage in discretionary or rule-based FX interventions that can alter the exchange rate channel.

There are several factors that can potentially weaken the interest rate channel. First, the international experience has shown that in many cases, central banks do not implement a fully conventional market-based monetary policy, with the objective of aligning a short-term money market rate on a key policy rate.

Second, countries' experiences also revealed that some central banks' liquidity management frameworks are insufficiently streamlined and use an array of monetary operations and different policy rates - even in normal times - that can undermine the signaling of monetary policy. Some central banks have also attempted to introduce market-based instruments while at the same time keeping direct instruments in place.

Third, there are situations where central bank actions on short-term interest rates are not transmitted to market rates because there is no active interbank uncollateralized or repo market, and/or no deep domestic sovereign bond market. In the absence of an active interbank market (collateralized or uncollateralized), the central bank may not be able to steer a short-term money market reference rate using its policy rate. The absence of a money market or a sovereign yield curve that can serve as reference for bank lending rates can also weaken the interest rate channel, most notably the ability of a short-term interest rate to have the desired impact on the yield curve.

Fourth, the central bank may not always be able or willing to fully sterilize liquidity surpluses at the appropriate level of interest rate, often due to sterilization cost concerns. As a result, downward pressures on short-term interest rates can develop, which can widen the gap with long-term interest rates. Long-term interest rates will, however, often remain mostly influenced by inflation expectations, and by the supply and demand for government securities, as well as the depth of financial markets.

Fifth, in the absence of appropriate liquidity forecasting and management framework, the central bank is unable to adequately calibrate the volume of its standard liquidity management operations and offset the liquidity shocks induced by autonomous factors. When the central bank's monetary operations are not accurately calibrated, they can add shocks to the system. 
Finally, in highly troubled banking systems, the level of short-term interest rates sometimes reflects financial stability issues more than macroeconomic development or the level of excess liquidity in the banking system. When credit risk is elevated and the banking system is in crisis, some banks may increase the level of their deposit rates to counteract a deposit runoff, while others may increase their interbank lending rate due to a lack of trust in their counterparties.

An interest rate-based monetary policy works through the dominant influence of the interest rate on key macro-financial variables, assuming a robust interest rate and liquidity management by the central bank. Under such policy, it is assumed that the central bank is able to control short-term interest rates and that changes in those rates are transmitted to the exchange rate, to market rates, to bank lending and deposits rates, to aggregate demand, and ultimately to inflation. In the presence of an impaired interest rate channel, central banks' actions on the exchange rate may prove to be more effective in stabilizing inflation than their actions on interest rates.

\section{Central Bank Monetary Policy Rules}

The literature reveals different types of monetary policy rules used when the exchange rate is pegged or tightly managed. Although there is no textbook formula for aptly specifying the reaction function under an exchange rate anchor, four monetary policy rules have been identified, depending on how the central bank manages the exchange rate anchor.

When the exchange rate is clearly and officially pegged, the two following reaction functions can be considered:

1. An interest rate rule including the policy rate of the anchor country $i_{t}^{*}$ and a risk premium Prem $_{t}$ (that is, a UIP condition):

$\mathrm{i}_{\mathrm{t}}=\mathrm{i}_{\mathrm{t}}^{*}+$ Prem $_{\mathrm{t}}$

2. A forward-looking interest rate rule including the policy rate of the anchor country as well as inflation and output gaps $\left(\mathrm{TR}+\mathrm{i}_{\mathrm{t}}^{*}\right)$ :

$\mathrm{i}_{\mathrm{t}}=\alpha_{1} \mathrm{i}_{\mathrm{t}}^{*}+\alpha_{2} \overline{\mathrm{i}}+\alpha_{3}\left(\mathrm{E}\left[\pi_{\mathrm{t}+\mathrm{n}} \mid \Omega_{\mathrm{t}}\right]-\pi^{\mathrm{T}}\right)+\alpha_{4}\left(\mathrm{E}\left[\mathrm{y}_{\mathrm{t}} \mid \Omega_{\mathrm{t}}\right]-\mathrm{y}^{\mathrm{T}}\right)$

Where $\overline{\mathrm{i}}$ is the long-run equilibrium nominal interest rate, $\pi_{\mathrm{t}+\mathrm{n}}$ is the inflation rate between periods $t$ and $t+n, \pi^{T}$ is the inflation target, $y_{t}$ is the real output, $y^{T}$ is potential output, $E$ is the expectation operator, and $\Omega_{\mathrm{t}}$ the information available at the central bank at the time it sets the policy rate.

When the exchange rate is not strictly pegged but rather stabilized or tightly managed or when the country is attempting an adjustment in its exchange rate, the two following reaction functions can be considered: 
3. A forward-looking ER rule (ERR) where the change in the nominal effective exchange rate (NEER), $e_{t}$, substitutes the interest rate in the TR:

$\Delta \mathrm{e}_{\mathrm{t}}=\gamma \Delta \overline{\mathrm{e}}+\alpha\left(\mathrm{E}\left[\pi_{\mathrm{t}+\mathrm{n}} \mid \Omega_{\mathrm{t}}\right]-\pi^{\mathrm{T}}\right)+\beta\left(\mathrm{E}\left[\mathrm{y}_{\mathrm{t}+\mathrm{n}} \mid \Omega_{\mathrm{t}}\right]-\mathrm{y}^{\mathrm{T}}\right)$

4. Since the previous rule, does not provide guidance for the policy rate, an interest rate rule can still be specified as a combination of a UIP condition and TR (UIP+TR):

$\mathrm{i}_{\mathrm{t}}=\mathrm{g}$ UIP $+(1-\mathrm{g}) \mathrm{TR}$

In case of an exchange rate anchor against a single currency, the UIP condition can be used as a reaction function. The choice of a UIP condition as a monetary policy rule assumes that the policy rate does not react to the business cycle but only to the monetary policy of the anchor country (for example, the case of Denmark).

By contrast, $\mathrm{TR}+\mathrm{i}_{\mathrm{t}}^{*}$ assumes some degree of influence/pass-through of the policy rate to output and inflation. The TR including the foreign interest rate $\left(\mathrm{TR}+\mathrm{i}_{\mathrm{t}}^{*}\right)$ is an extension of the one that has been tested by Clarida, Galí, and Gertler (1998) as the reaction function possibly characterizing monetary policy in France, Italy, and the United Kingdom (UK) before the crisis of the European Monetary System (EMS) in $1992^{20}$. In their paper, the authors document the strong influence of the Bundesbank monetary policy on that of Banque de France, Banca d'Italia, and Bank of England. Following Clarida, Galí and Gertler (1998), the forward-looking version of the TR could be extended to include the foreign interest rate when the central bank participates in an exchange rate system.

However, the implication was that the central banks of France, Italy, and the UK pursued policies of relatively high real short-term interest rates even during periods of low inflation. In practice, these central banks' reaction function, which implicitly included the Bundesbank policy rate $\left(\mathrm{TR}+\mathrm{i}_{\mathrm{t}}^{*}\right)$ revealed problematic in the presence of sizable capital flows. At the time of the EMS crisis, large capital outflows from France, Italy, or the UK to Germany have tested the resilience of the EMS. In the absence of sufficient FX reserves, higher policy rates were requested to counterbalance these capital flows. However, higher policy rates would undermine economic growth. Countries were hence facing the dilemma between hiking interest rates and depleting their FX reserves and potentially exceeding the agreed fluctuation bands under the EMS, meaning leaving the EMS, which happened eventually for the UK.

Where the exchange rate pass-through allows the central bank to influence inflation through the exchange rate, an ERR is an option to consider. For example, the MAS uses an ERR but officially relinquishes control over the level of domestic interest rates. Nonetheless, even if the MAS is not directly setting the level of short-term interest rates, the relationship between

\footnotetext{
${ }^{20}$ Under the EMS, countries agreed to keep their foreign exchange rates within narrow bands $(+/-2.25 \%)$. In practice, the Deutsche mark emerged as the currency anchor.
} 
the interest rate and the exchange rate in Singapore would be well-characterized by the UIP condition $^{21}$.

Some countries maintaining capital controls and currently attempting further exchange rate flexibility are including in their QPM, monetary policy rules specified as a combination of a UIP condition and a TR (UIP+TR). This is for example the case of Morocco with the MQPM including the following policy rule ${ }^{22}$ :

$\mathrm{i}_{\mathrm{t}}=\omega_{\mathrm{ip}} \mathrm{ip}_{\mathrm{t}}+\left(1-\omega_{\mathrm{ip}}\right)$ iuip $_{\mathrm{t}}$

$\mathrm{ip}_{\mathrm{t}}=\alpha_{1} \mathrm{ip}_{\mathrm{t}-1}+\left(1-\alpha_{1}\right)\left(\overline{\mathrm{ip}}+\alpha_{2} \pi_{\mathrm{t}+3}^{\mathrm{dev}}+\alpha_{3} \widehat{\mathrm{dd}}_{\mathrm{t}}\right)+\varepsilon_{\mathrm{t}, \mathrm{ip}}$

iuip $_{\mathrm{t}}=\mathrm{i}_{\mathrm{t}}^{\mathrm{ez}}+\operatorname{Prem}_{\mathrm{t}}+\left(\mathrm{E}_{\mathrm{t}}\left(\mathrm{MAD} / \mathrm{EUR}_{\mathrm{t}+1}\right)-{\left.\mathrm{MAD} / \mathrm{EUR}_{\mathrm{t}}\right)}\right)$

Where:

$\mathrm{ip}_{\mathrm{t}} \quad$ is the interbank rate

$\overline{\mathrm{ip}} \quad$ is the natural rate of interest

iuip $_{\mathrm{t}} \quad$ UIP-implied interest rate

$\pi_{\mathrm{t}+3}^{\mathrm{dev}}$ is the $t+3$ period ahead deviation of the inflation rate from the implicit target

$\widehat{\mathrm{dd}}_{\mathrm{t}}$ is the domestic demand gap

$\mathrm{i}_{\mathrm{t}}^{\mathrm{ez}} \quad$ is the foreign interest rate

Prem $_{t} \quad$ is the country risk premium

$\mathrm{MAD} / \mathrm{EUR}$ is the dirham-to-euro nominal exchange rate

$\omega_{\text {ip }} \quad$ is the weight assigned to $\mathrm{ip}_{\mathrm{t}}$

${ }^{21}$ MAS (2004).

${ }^{22}$ Benlamine, Laxton, and others (2018). 
Figure 8. Monetary Policy Rules, Exchange Rate Arrangements, and Capital Account Openness

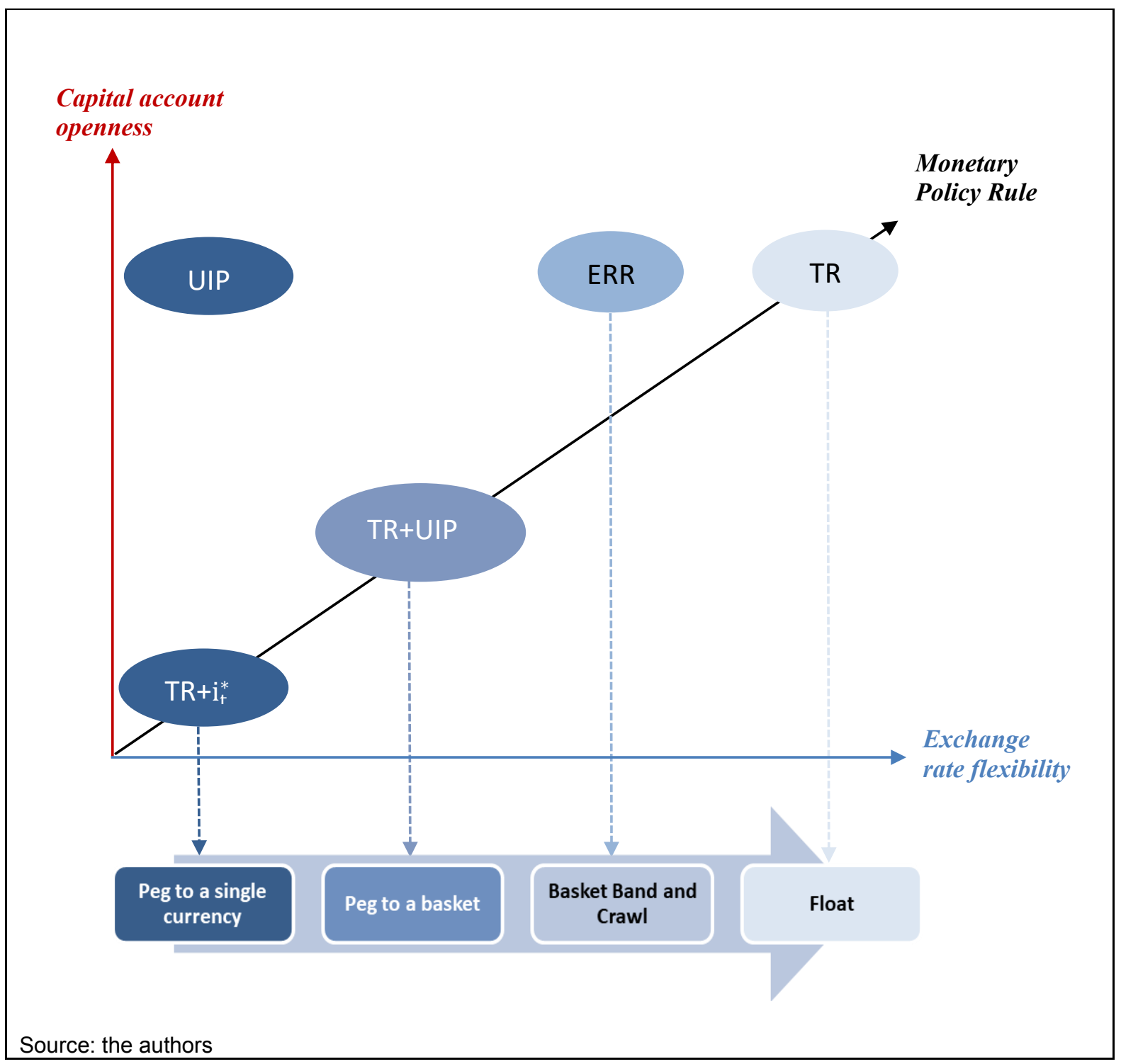




\section{Liquidity MAnagement Under an EXChange Rate AnCHOR}

\section{A. Introduction of an Interest Rate Corridor System}

A corridor system is not incompatible with a fixed exchange rate regime, either conceptually or empirically. Morocco is one example of a country that Figure 9. Morocco Interest Rate Mid-Corridor introduced an interest rate midcorridor system under a peg to a currency basket. Morocco also maintains selected capital controls (Figure 9).

In modern monetary policy frameworks, the level of the policy rate is set by an independent board or MPC, and the operational process of stabilizing a short-term money market rate, within a corridor system, for example, is a separate process. Bindseil (2016) highlights this separation or "dichotomy" principle_-already implemented by a number of central System banks years ago - that applies between the macroeconomic analysis that supports the setting of the policy rate, and the operational implementation of monetary policy.

Countries with fixed or tightly managed exchange rate can - under certain conditions implement an interest rate mid-corridor system that stabilizes short-term money market rates. There are, however, supporting conditions to the successful implementation of a mid-corridor under an exchange rate anchor, including: (1) an adequate liquidity forecasting framework; (2) an active interbank market; (3) clear separation between the monetary policy operational framework and emergency liquidity assistance (ELA) framework; (4) relatively developed fixed income markets that provide sufficient eligible collateral and longer-term funding instruments for banks and that alleviate the over-reliance on central bank funding; and (5) the absence of high levels of speculation against the local currency.

There is "good" and "bad" timing for introducing an interest rate mid-corridor system. In particular, central banks operating fixed or tightly managed exchange rate may find it difficult to introduce corridors in times of unsustainable depreciation expectations and rapidly decreasing net foreign assets (NFA). Reconciling the two objectives of setting a firm corridor ceiling and fighting speculative attacks may not be feasible. Introducing a corridor system has a higher chance of success during period of FX reserve accumulation or when the market is about to smoothly transition from a liquidity surplus to a deficit. 
When trying to introduce a mid-corridor system, financial conditions can initially weigh on interbank rates and may induce downward or upward pressures. Downward pressures are typically observed in excess liquidity situations, when the central bank has not yet set an overnight standing deposit facility that puts a firm floor on interbank rates. Upward pressures can emerge in the presence of unsustainable depreciation expectations or during banking crises when credit risks are elevated. In such cases, to avoid shocking the system, it is preferable to start with a relatively wide corridor that can be gradually narrowed (Figure 10).

Figure 10. Example of the Gradual Introduction of an Interest Rate Corridor

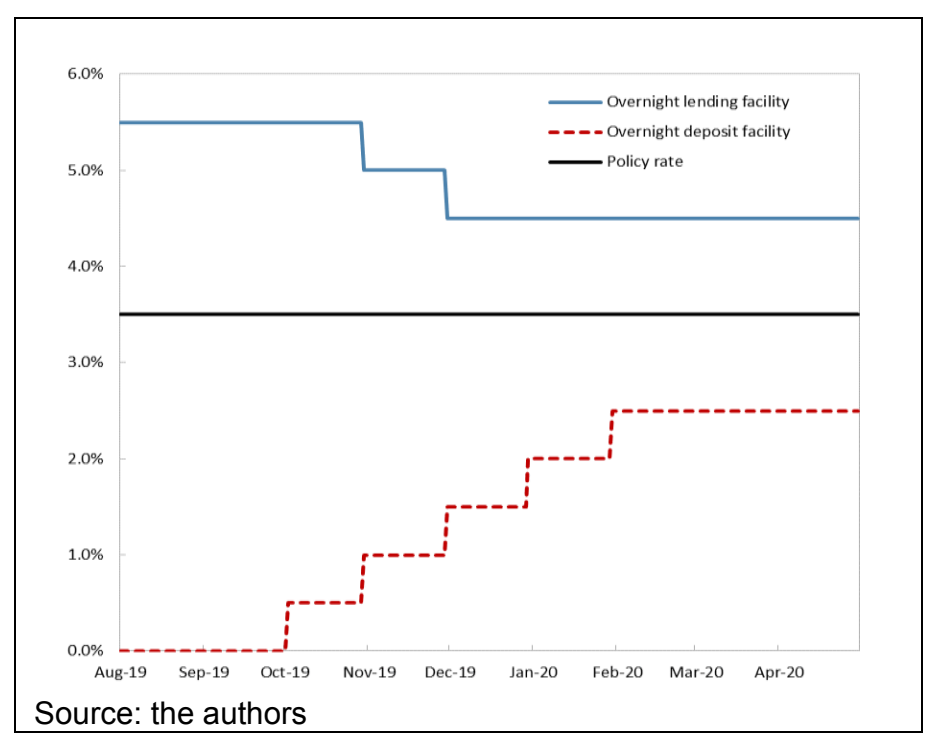

\section{B. The Corridor Versus Floor System}

While recognizing that not all countries are able to implement a mid-corridor system all the time under all conditions, a floor system can have some drawbacks when the exchange rate is fixed or heavily managed. This is because draining surplus liquidity mainly on an overnight maturity at the initiative of banks (especially at low interest rates), is almost equivalent to leaving free reserves in the banking system, which can exert some pressure on international reserves and the peg. Draining surplus liquidity structurally or on longer maturities is thus important under fixed exchange rate arrangements.

A standard mid-corridor system operates with a unique overnight standing lending facility and a unique overnight standing deposit facility that act as a corridor ceiling and floor and contain money market rate fluctuations within a specific range. Standard or main OMOs conducted on a regular basis, could be set at a maturity longer than overnight (for example, one week) to foster money market development when markets are shallow. A full-allotment may not be optimal in the case of a liquidity-providing OMO, while having a fixed or tightly managed exchange rate. It is often preferable to calibrate standard OMOs according to autonomous factor forecasts, as the full allotment may result in an over-injection of liquidity that can fuel the demand for FX at the central bank, increasing the pressure on its FX reserves ${ }^{23}$.

\footnotetext{
${ }^{23}$ See El Hamiani Khatat and Veyrune (2019) for a more detailed discussion on liquidity management under fixed exchange rate.
} 


\section{The Tiering Floor System Under an Exchange Rate Anchor}

Some central banks have introduced a tiering system in which different interest rates are applied to counterparties' reserves. Central banks with free-floating exchange rates such as the Central Bank of Norway have implemented, since 2011, a tiering system to limit the demand for reserves and support money market functioning. More recently, tiering was introduced by some central banks, such as the Swiss National Bank, Bank of Japan, and the $\mathrm{ECB}$, to support monetary policy transmission in a negative interest rate environment.

Within a floor system under an exchange rate anchor, tiering can be introduced to avoid the build-up of large and freely available deposits that may be used for speculation, while ensuring functioning day-to-day liquidity management by counterparties. For example, the DNB has set a ceiling for counterparties' aggregated current account deposits (current account limits). Counterparties use their funds on current account deposits as means of payment, and settle transactions among themselves and with the DNB, using the DNB's payment system Kronos. Funds are remunerated at the current account deposit rate. If the overall limit for all counterparties is exceeded, current-account deposits exceeding the individual limits are converted into CDs. Individual current account limits are determined as a percentage of each bank's krone deposits from customers ${ }^{24}$.

In the past, the DNB has actively changed the aggregate current account limits to support counterparties' liquidity management. During episodes of large demand for liquidity, such as in 2008, the DNB suspended current account limits. With the introduction of negative interest rates in 2012 and in 2015, the DNB temporarily increased current account limits to reduce counterparties' overall costs for holding deposits in an environment of negative interest rates and a high net liquidity position of the banking system. Presently, counterparties are using their current account fully, reflecting rate differences of the current account ( 0 percent) and DNB CDs (currently -0.60 percent $)^{25}$.

The DNB's standard OMOs include three types of operations: (1) weekly OMOs; (2) daily OMOs; and (3) liquidity adjusting operations. First, weekly OMOs include monetary policy loans against collateral (at the lending rate). Second, daily OMOs consist of the DNB's offers to buy or sale (on a daily basis) CDs maturing on the last banking day of the week. A premium is added to the CDs' interest rate when calculating the CDs' price, creating an incentive to exchange liquidity in the money market instead of selling the CDs back to the DNB. The introduction of the daily purchase or sale of CDs in 2017 has successfully reduced

\footnotetext{
${ }^{24}$ Presently, each counterparty is awarded a current account limit equal to 3 percent of its deposits up to DKK 2 billion and 1.7 percent on deposits above 2 billion. This ensures that the smaller banks have a larger percentage of their deposits as current account limit. Mortgage credit institutions have a current account limit of DKK 500 million.

${ }^{25}$ Before the introduction of negative interest rates, counterparties generally maximized amounts deposited in CDs, and current account deposits were held significantly below current account limits.
} 
the volatility in short term money market rates $^{26}$ and other longer-term reference interest rates. Third, liquidity-adjusting operations are conducted in various forms, as deposits, lending against collateral, and FX swaps. For these operations, the DNB provides or absorbs liquidity via auction or conducts bilateral transactions.

The DNB's set of instruments does not contain a marginal lending facility. As a result, money market rates are not capped, but are able to rise freely in case of exchange rate pressures and capital outflows. It is assumed that freely rising interest rates will inherently dampen the outflow of FX, thereby supporting the fixed exchange rate arrangement.

From mid-2009 to early 2020, the net liquidity position of counterparties has been significantly positive. As a result, counterparties have accessed only sporadically and at low amounts DNB monetary policy loans against collateral. In early 2012, three-year monetary policy loans were introduced to increase the availability of long-term funding for counterparties. This also reflected similar three-year loans introduced by the ECB.

Figure 11. Danmarks Nationalbank Policy Rates and Liquidity Management Instruments

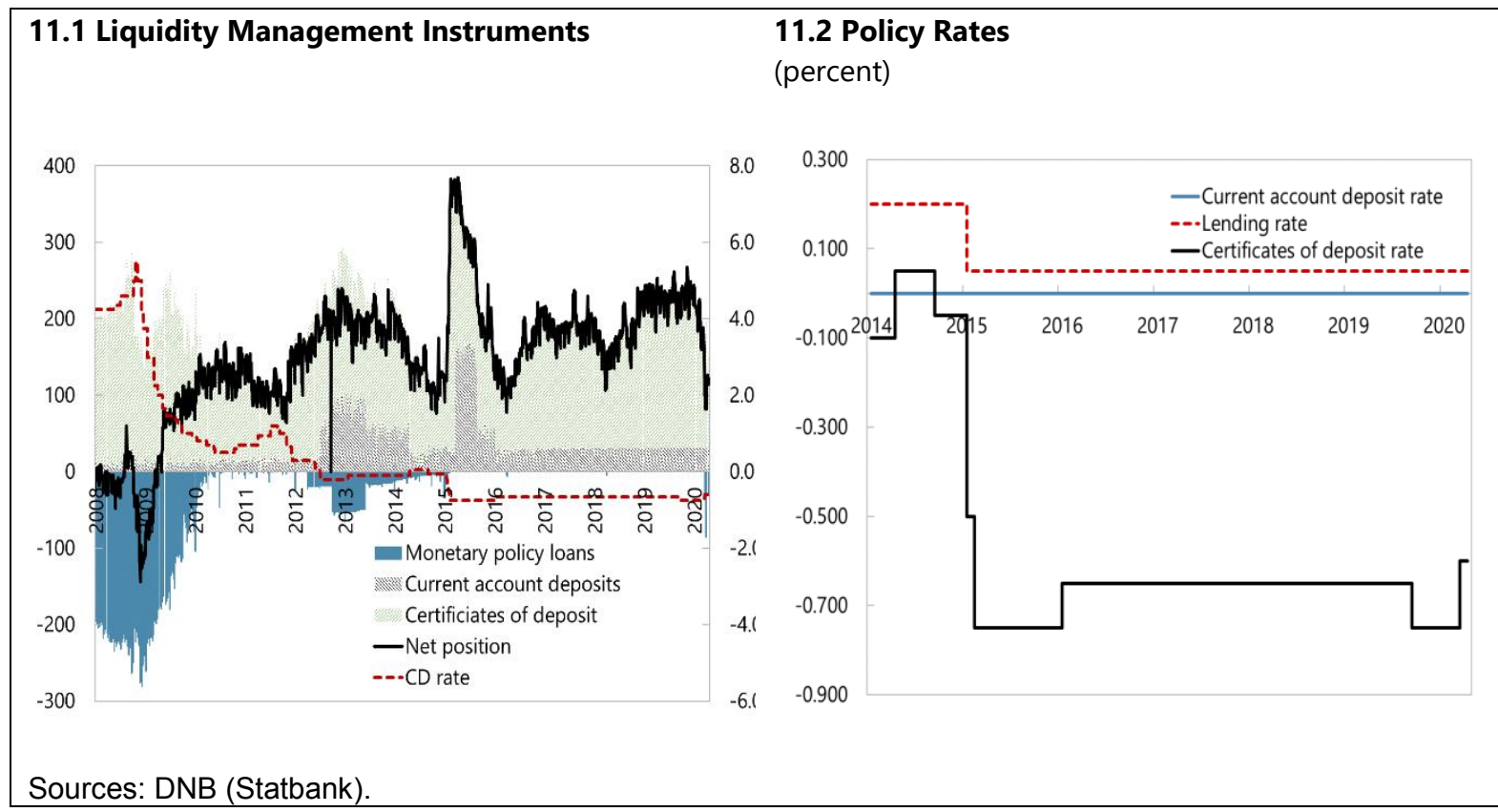

${ }^{26}$ This volatility was a consequence of the widened interest rate corridor (current account rate-CD rate), and the absence of a central bank facility that allowed for depositing or lending central bank liquidity on a daily basis, between two weekly operations. 


\section{Transitioning The Exchange Rate ArRangement}

To remain sustainable, exchange rate anchoring regimes need adequate international reserves and sometimes even an increasing NFA path and preferably a stream of current account surpluses. When NFA are depleted or on a persistently decreasing path, such regimes can become prone to speculation and unsustainable over time. Maintaining a permanently increasing trend of NFA and an appreciation trend of the local currency depends not only on monetary and fiscal policy discipline, but also on global factors. Therefore, countries operating an exchange rate anchor may have to adjust their exchange rate arrangement at some point.

The international experience has shown that there are different possible paths for increasing exchange rate flexibility. Moving from an exchange rate-based to an interest rate-based monetary policy in an orderly fashion has often required transitioning through multiple exchange rate arrangements. It also requires a high degree of central bank independence, strong coordination between the central bank and the Ministry of Finance, as well as institutions' capacity to rapidly adapt, including by revising their internal organization and governance and by strengthening human resources and analytical and modelling capacity.

The experiences of countries that have managed such transition vary greatly. Some countries have moved gradually (Chile, Israel, and Poland) while others rapidly and disorderly due to pressure (Brazil, Czech Republic, and Uruguay) ${ }^{27}$. Countries that have achieved a successful transition have in some cases implemented a peg against a currency basket. In addition, some countries have opted for a crawling arrangement along the road, while others have chosen a gradual widening of the exchange rate bands (Figures 12 and 13).

When early transitioning from a peg to a more flexible exchange rate arrangement, transitional arrangements can include moving from a peg to a single currency to a basket in a first phase, and a more dynamic management of the basket in the second phase by adopting, for example, a BBC arrangement. The transitional arrangement can also include a crawling peg or arrangement. All these exchange rate arrangements (peg against a single currency, peg against a basket of currency, crawling peg) can fall into the category of exchange rate anchor. In other words, the central bank can try to better manage the exchange rate even within the exchange rate anchoring regime.

During such transition, the central bank monetary policy rule may need to be revised and recalibrated to fit the transitional exchange rate arrangement in place. Where an interest rate pass-through to inflation has been clearly evidenced, the interest rate can be linked to an inflation target allowing the central bank to operate a form of TR or a combination of a TR and a UIP condition. However, it can be the case that no interest rate pass-through or a very

${ }^{27}$ Ötker-Robe and others (2007). 
weak and lengthy impact of the key policy rate to inflation is found. In such cases, the central bank monetary policy rule may take the form of an ERR.

Figure 12. Moving Toward Greater Exchange Rate Flexibility-Transitional Exchange Rate Arrangements Adopted by Selected Countries

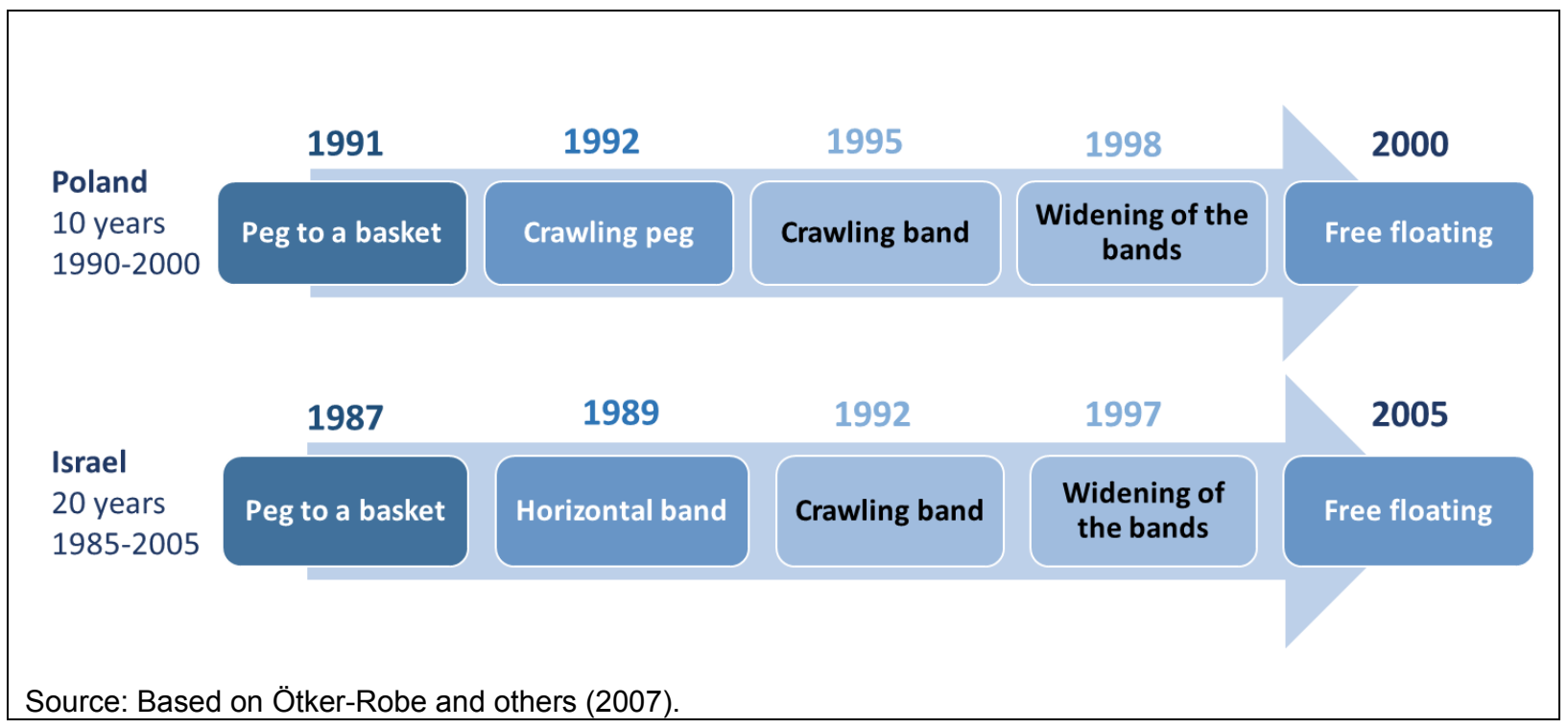

Figure 13. Stylized Transitional Exchange Rate Arrangements

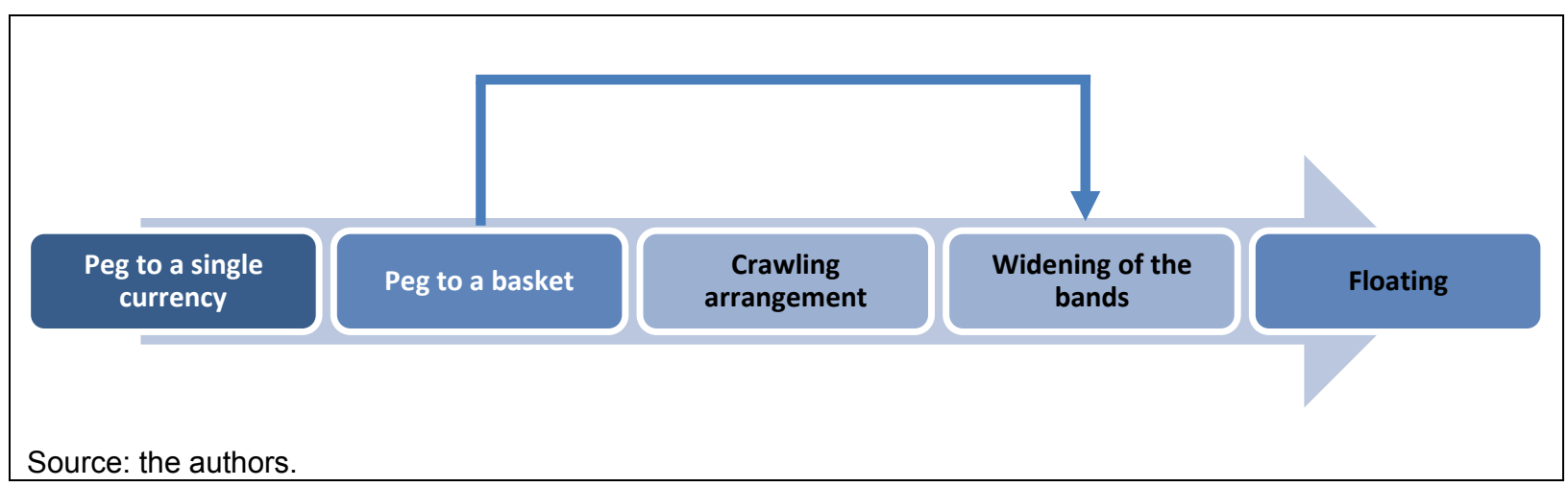




\section{Conclusion}

This paper suggests that monetary policy design and implementation can follow broadly similar principles and processes under an exchange rate-based monetary policy as under an interest rate-based monetary policy, when the authorities clearly understand and embed the main findings of the paper and supported by the international experiences of countries adopting soft pegs.

First, an exchange rate-based monetary policy is different from an interest rate-based monetary policy with FX interventions. Under an interest rate-based monetary policy with FX interventions, the main monetary policy instrument used by the central bank to smooth out the business cycle is the interest rate, while FX interventions usually strive to dampen exchange rate volatility. Under an exchange rate-based monetary policy, the main lever used to stabilize inflation is the exchange rate. Consequently, the literature that applies to IT regimes with FX interventions is only partially relevant for countries operating exchange rate anchors.

Second, the short-term interest rate and the exchange rate are tied by an interest rate parity condition and should be managed coherently, with the view of achieving the final objective of price stability. Inflation can remain the final objective under an exchange rate anchor, while the exchange rate is the nominal anchor and the main monetary policy instrument. The policy rate can have a different objective than smoothing out the business cycle, and the monetary policy rule can be different from a standard forward-looking TR. Liquidity management retains the important role of stabilizing money market rates and anchoring market expectations. The liquidity management framework should be designed to curtail liquidity surpluses and often limit quantitative measures or over-injection of central bank liquidity that can put pressure on international reserves and the exchange rate.

Third, exchange rate anchors are more prone to policy inconsistencies, calling for fiscal and monetary discipline. The commitment to a soft peg constrains the authorities' ability to engage in expansionary fiscal and quantitative monetary policies. An exchange rate anchor is hardly compatible with fiscal dominance, and with a conventional MT regime. In addition, soft pegs can induce exchange rate levels and movements inconsistent with balance of payment developments, highlighting the need for timely and well-designed strategies to evolve the exchange rate arrangement.

Finally, an exchange rate anchor becomes unsustainable when international reserves are depleted. Moving from an exchange rate anchor to an interest rate-based monetary policy in an orderly fashion has often been gradual and involved evolving the exchange rate through multiple transitional arrangements. The adoption of an interest rate corridor can support such a move, as it provides the central bank with a better control over short-term interest rates. The introduction of the interest rate corridor can be gradual, with a steady narrowing of the corridor width. While a corridor system might be easier to introduce under partial capital 
controls, or when the regime is not subject to highly speculative pressures, a tiering floor could also be envisaged when the country faces sizeable capital flows. 


\section{Appendix I. Overview of Countries Adopting an Exchange Rate Anchor}

Countries with an exchange rate anchor ${ }^{28}$ are a disparate group of 81 high-, middle-, and lowincome countries, the largest share of which includes Sub-Saharan Africa (SSA) countries, Middle East and Central Asia countries, and islands (Appendix I. Table 1, and Appendix II). Exchange rate targeters include two monetary unions - CEMAC (Communauté Économique et Monétaire de l'Afrique Centrale), and WAEMU (West African Economic and Monetary Union); the ECCU (East Caribbean Currency Union) countries opted for a currency board. Soft pegs are divided into four arrangements:

1. Conventional pegs, the largest share being pegged to the euro (18 countries), followed by pegs to the US dollar (14 countries) and five pegs to other currencies (Bhutan, Eswatini, Lesotho, Namibia, and Nepal). Four of the countries have their currencies pegged against a basket of foreign currencies (Fiji, Kuwait, Libya, and Morocco).

2. Stabilized arrangements include eight countries, four of which stabilize their currencies against the USD dollar (Guyana, Lebanon, Maldives, and Trinidad and Tobago). Croatia and North Macedonia currencies are stabilized against the euro, and Singapore and Vietnam against a composite of foreign currencies.

3. Crawling pegs include Botswana, Honduras, and Nicaragua.

4. Crawl-like arrangement is adopted by Iran only while no country has an exchange rate pegged within horizontal bands, according to the AREAER 2018.

The largest share of the countries classified by the AREAER 2018 have an exchange rate anchor as the monetary policy framework $(42 \%)$, followed by other monetary policy frameworks (24\%), inflation targeters (21\%), and monetary targeters (13\%) (Figure I.1).

\footnotetext{
${ }^{28}$ According to the IMF classification (AREAER 2018).
} 
Appendix I. Figure 1. Countries Monetary Policy Frameworks

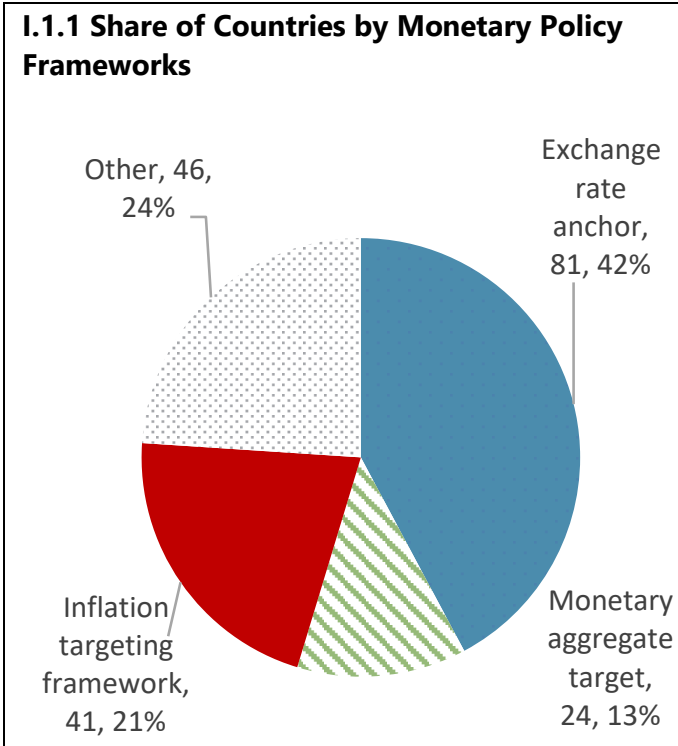

I.1.2 Exchange Rate Anchor by Category of Exchange Rate Regime

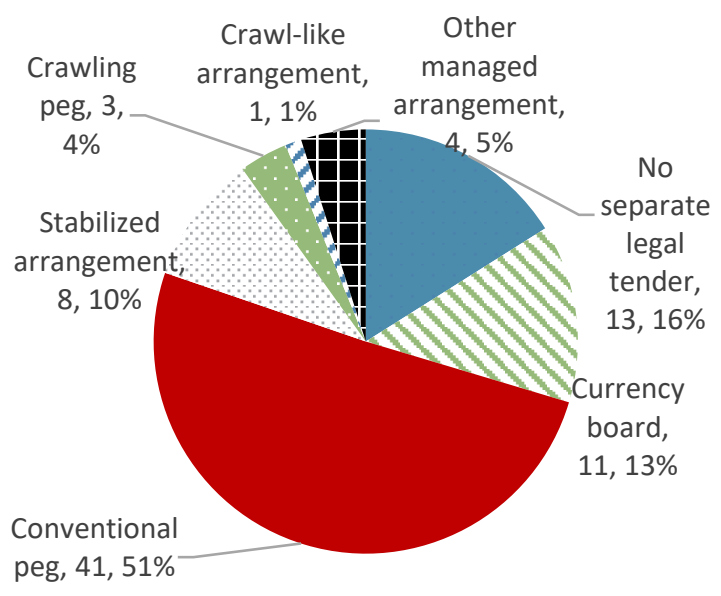

Source: AREAER 2018

Appendix I. Table 1. Countries with an Exchange Rate Anchor Excluding Countries with no Separate Legal Tender and Currency Boards

\begin{tabular}{|c|c|c|c|c|}
\hline $\begin{array}{l}\text { SSA countries } \\
\text { (19) }\end{array}$ & $\begin{array}{l}\text { MCD countries } \\
\text { (13) }\end{array}$ & $\begin{array}{l}\text { Islands } \\
(10)\end{array}$ & $\begin{array}{c}\text { Advanced economies } \\
\text { (2) }\end{array}$ & $\begin{array}{l}\text { Other countries } \\
(9)\end{array}$ \\
\hline $\begin{array}{l}\text { CEMAC } \\
\text { Cameroon } \\
\text { Central African } \\
\text { Rep. } \\
\text { Chad } \\
\text { Rep. of Congo } \\
\text { Equatorial } \\
\text { Guinea } \\
\text { Gabon } \\
\text { WAEMU } \\
\text { Benin } \\
\text { Burkina Faso } \\
\text { Côte d'Ivoire } \\
\text { Guinea-Bissau } \\
\text { Mali } \\
\text { Niger } \\
\text { Senegal } \\
\text { Togo } \\
\text { OTHER } \\
\text { Botswana } \\
\text { Eritrea } \\
\text { Eswatini } \\
\text { Lesotho } \\
\text { Namibia }\end{array}$ & $\begin{array}{l}\text { CCA } \\
\text { Turkmenistan } \\
\text { GCC } \\
\text { Bahrain } \\
\text { Kuwait } \\
\text { Oman } \\
\text { Qatar } \\
\text { United Arab } \\
\text { Emirates Saudi } \\
\text { Arabia } \\
\text { NORTH AFRICA } \\
\text { Libya } \\
\text { Morocco } \\
\text { OTHER } \\
\text { Iran } \\
\text { Iraq } \\
\text { Jordan } \\
\text { Lebanon }\end{array}$ & $\begin{array}{l}\text { Aruba } \\
\text { The Bahamas } \\
\text { Barbados } \\
\text { Cabo Verde } \\
\text { Comoros } \\
\text { Curaçao and Sint } \\
\text { Maarten } \\
\text { Maldives } \\
\text { Fiji } \\
\text { São Tomé and } \\
\text { Príncipe } \\
\text { Trinidad and } \\
\text { Tobago }\end{array}$ & $\begin{array}{l}\text { Denmark } \\
\text { Singapore }\end{array}$ & $\begin{array}{l}\text { AMERICAS } \\
\text { Belize } \\
\text { Guyana } \\
\text { Honduras } \\
\text { Nicaragua } \\
\text { ASIA } \\
\text { Bhutan } \\
\text { Nepal } \\
\text { Vietnam } \\
\text { EUROPE } \\
\text { Croatia } \\
\text { North Macedonia }\end{array}$ \\
\hline
\end{tabular}




\section{Appendix II. Monetary Policy Frameworks and Exchange Rate Arrangements of Countries Adopting an Exchange Rate Anchor ${ }^{29}$}

\begin{tabular}{|c|c|c|c|c|c|c|}
\hline \multirow{3}{*}{$\begin{array}{l}\text { Exchange Rate } \\
\text { Arrangement } \\
\text { (number of } \\
\text { countries) } \\
\end{array}$} & \multicolumn{6}{|c|}{ Monetary Policy Framework } \\
\hline & \multicolumn{6}{|c|}{ Exchange Rate Anchor (57) } \\
\hline & \multicolumn{2}{|c|}{$\begin{array}{l}\text { US Dollar } \\
\text { (20) }\end{array}$} & \multicolumn{2}{|c|}{$\begin{array}{l}\text { Euro } \\
(20)\end{array}$} & \multirow{2}{*}{\begin{tabular}{l}
\multicolumn{1}{c}{$\begin{array}{c}\text { Composite } \\
(8)\end{array}$} \\
\\
\\
\\
\\
Fiji \\
Kuwait \\
Libya \\
Morocco
\end{tabular}} & $\begin{array}{l}\text { Other } \\
\text { (5) }\end{array}$ \\
\hline $\begin{array}{l}\text { Conventional peg } \\
\text { (41) }\end{array}$ & $\begin{array}{l}\text { Aruba } \\
\text { The Bahamas } \\
\text { Bahrain } \\
\text { Barbados } \\
\text { Belize } \\
\text { Curaçao } \\
\text { and Sint } \\
\text { Maarten } \\
\text { Eritrea }\end{array}$ & \begin{tabular}{l} 
Iraq \\
Jordan \\
Oman \\
Qatar \\
Saudi Arabia \\
Turkmenistan \\
United Arab \\
\multicolumn{1}{c}{ Emirates }
\end{tabular} & $\begin{array}{l}\text { Cabo Verde } \\
\text { Comoros } \\
\text { Denmark } \\
\text { São Tomé and } \\
\quad \text { Príncipe } \\
\text { WAEMU } \\
\text { Benin } \\
\text { Burkina Faso } \\
\text { Côte d'Ivoire } \\
\text { Guinea-Bissau } \\
\text { Mali } \\
\text { Niger } \\
\text { Senegal } \\
\text { Togo } \\
\end{array}$ & $\begin{array}{l}\text { CEMAC } \\
\text { Cameroon } \\
\text { Central } \\
\text { African } \\
\text { Rep. } \\
\text { Chad } \\
\text { Rep. of } \\
\text { Congo } \\
\text { Equatorial } \\
\text { Guinea } \\
\text { Gabon }\end{array}$ & & $\begin{array}{l}\text { Bhutan } \\
\text { Eswatini } \\
\text { Lesotho } \\
\text { Namibia } \\
\text { Nepal }\end{array}$ \\
\hline $\begin{array}{l}\text { Stabilized } \\
\text { arrangements (8) }\end{array}$ & $\begin{array}{l}\text { Guyana } \\
\text { Lebanon } \\
\text { Maldives } \\
\text { Trinidad and } \\
\quad \text { Tobago }\end{array}$ & & $\begin{array}{l}\text { Croatia } \\
\text { North } \\
\quad \text { Macedonia }\end{array}$ & & $\begin{array}{l}\text { Singapore } \\
\text { Vietnam }\end{array}$ & \\
\hline Crawling peg (3) & $\begin{array}{l}\text { Honduras } \\
\text { Nicaragua }\end{array}$ & & & & Botswana & \\
\hline $\begin{array}{l}\text { Crawl-like } \\
\text { arrangement (1) }\end{array}$ & & & & & Iran & \\
\hline $\begin{array}{l}\text { Pegged exchange } \\
\text { rate within } \\
\text { horizontal bands }\end{array}$ & & & & & & \\
\hline
\end{tabular}

Source: AREAER 2018.

${ }^{29}$ According to the IMF classification (AREAER 2018) and excluding countries with no separate legal tender and currency boards. 


\section{Appendix III. The Czech National Bank Exchange Rate Commitment}

On November 7, 2013, the CNB decided to use the exchange rate as an additional monetary policy instrument and announced a floor of 27 koruna to the euro after the lower bound on interest rates was reached. The key objective of conducting FX interventions to weaken the koruna was to prevent deflation and ensure that the CNB fulfills its inflation target of 2 percent. The exchange rate commitment has been effective in mitigating effects of the disinflationary shock (Caselli 2017). It also allowed the CNB to fulfill its secondary objective: to support the general economic policies of the government by helping to overcome a recession ${ }^{30}$.

Indeed, during 2012-13, the Czech economy went through a recession, with rising unemployment, falling consumption, and decreasing corporate profits and investment. The CNB reacted first by lowering interest rates to 0.05 percent in late 2012 . In addition, it committed to maintain the record-low level of interest rate as long as necessary. The CNB then started announcing in autumn 2012 that it was ready to use other instruments should further monetary policy easing become necessary. The announcement led to the weakening of the koruna in late 2012 and early 2013 which slowed the disinflation pressure.

Initially, the effect of a weaker koruna was not positive. Firms faced higher import prices (commodities, materials and semi-finished products), and households had to pay more for imported goods and energy. However, the side effect was short-lived and positive effects gradually prevailed. Over time, the weakening of the koruna against the euro increased import prices, boosting the demand for domestic goods. As a consequence, the Czech economy grew by 2 percent in 2014. Economic growth was also supported by recovering external demand, and higher government investment.

The CNB ended the exchange rate commitment in April 2017. Following the exit, an appreciation of the koruna against the euro initially fostered a shift of monetary conditions to normal. Capital inflows accelerated in the run-up to the exit bringing the stock of FX reserves to $70 \%$ of GDP. The CNB started to raise interest rates gradually in August $2017^{31}$. The slight overshooting of the inflation target, with inflation moving in the upper half of the tolerance band around the target during 2017, was due to the fact that the CNB - in line with its previous communications - discontinued its exchange rate commitment only when sustainable and robust fulfilment of the 2 percent inflation target had been ensured. Inflation

\footnotetext{
${ }^{30}$ https://www.cnb.cz/en/faq/What-was-the-exchange-rate-commitment/.

${ }^{31}$ Shabunina (2017) discusses the phasing out and aftermath of the CNB exchange rate floor regime and analyses the policy responses and possible errors under a set of plausible macroeconomic scenarios. The findings indicate that a monetary policy response that is ex post too loose is likely to be less costly than a monetary policy response that is ex post too tight. This suggests that a gradual approach to interest rate increases could be preferable.
} 
remained above the 2 percent target in 2017 but returned to the target in late 2018 due to the stabilizing effect of monetary policy and the appreciating koruna (Appendix III. Figure 1).

Appendix III. Figure 1. Czech Republic_Inflation, Policy Rate, and Exchange Rates

\section{III.1.2 Czech Republic Inflation and Policy Rate} (percent)

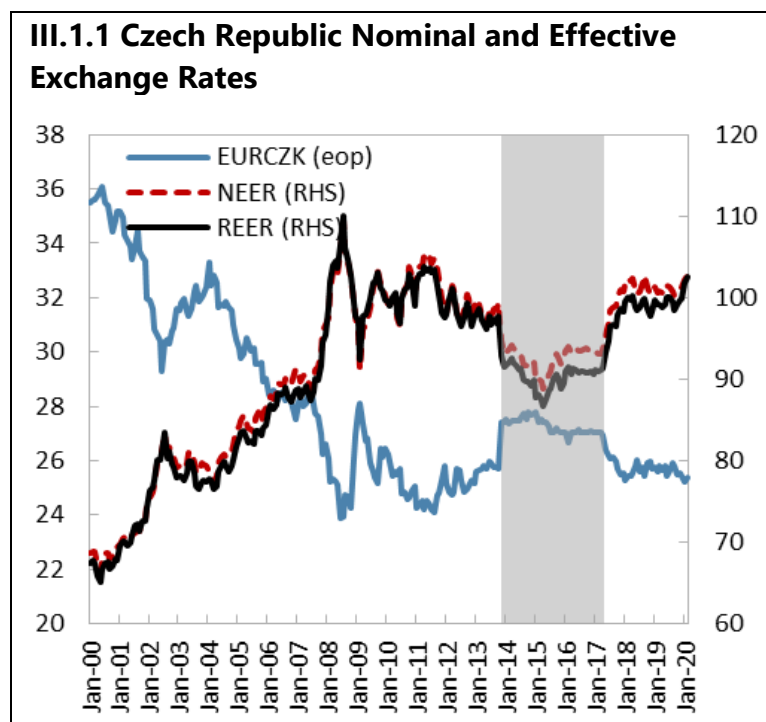

Source: IFS.

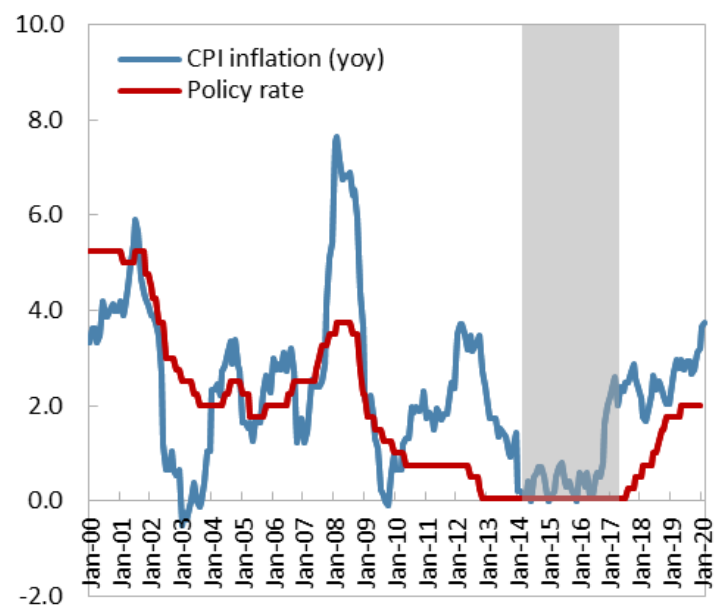




\section{Appendix IV. Main Supply and Demand Factors of Central Banks' Foreign Reserves}

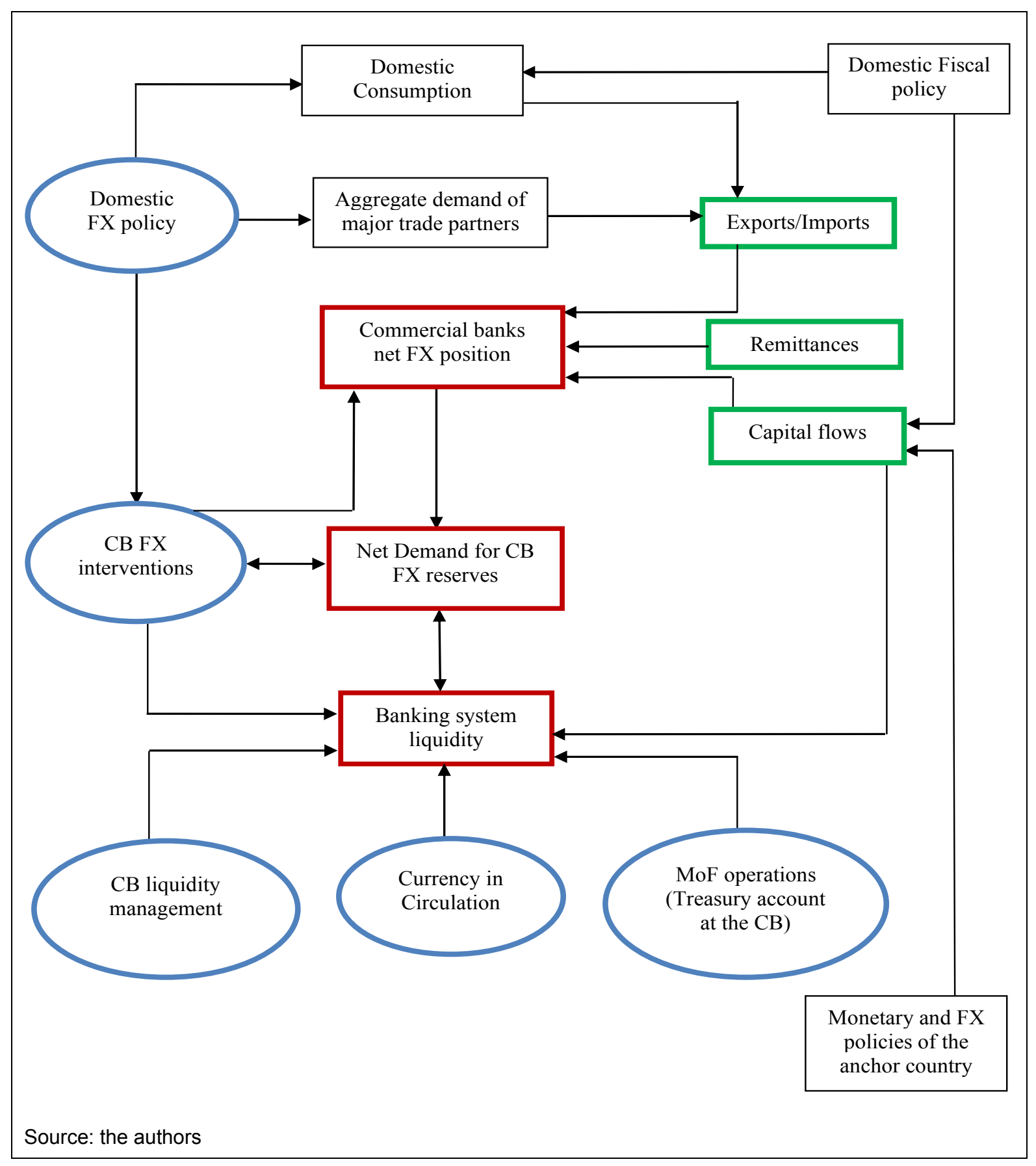




\section{Appendix V. Countries Pegging or Stabilizing Their Exchange Rate and Anchor Countries' Inflation}

Appendix V. Figure 1. Inflation in Selected Countries Pegging or Stabilizing their Exchange Rate

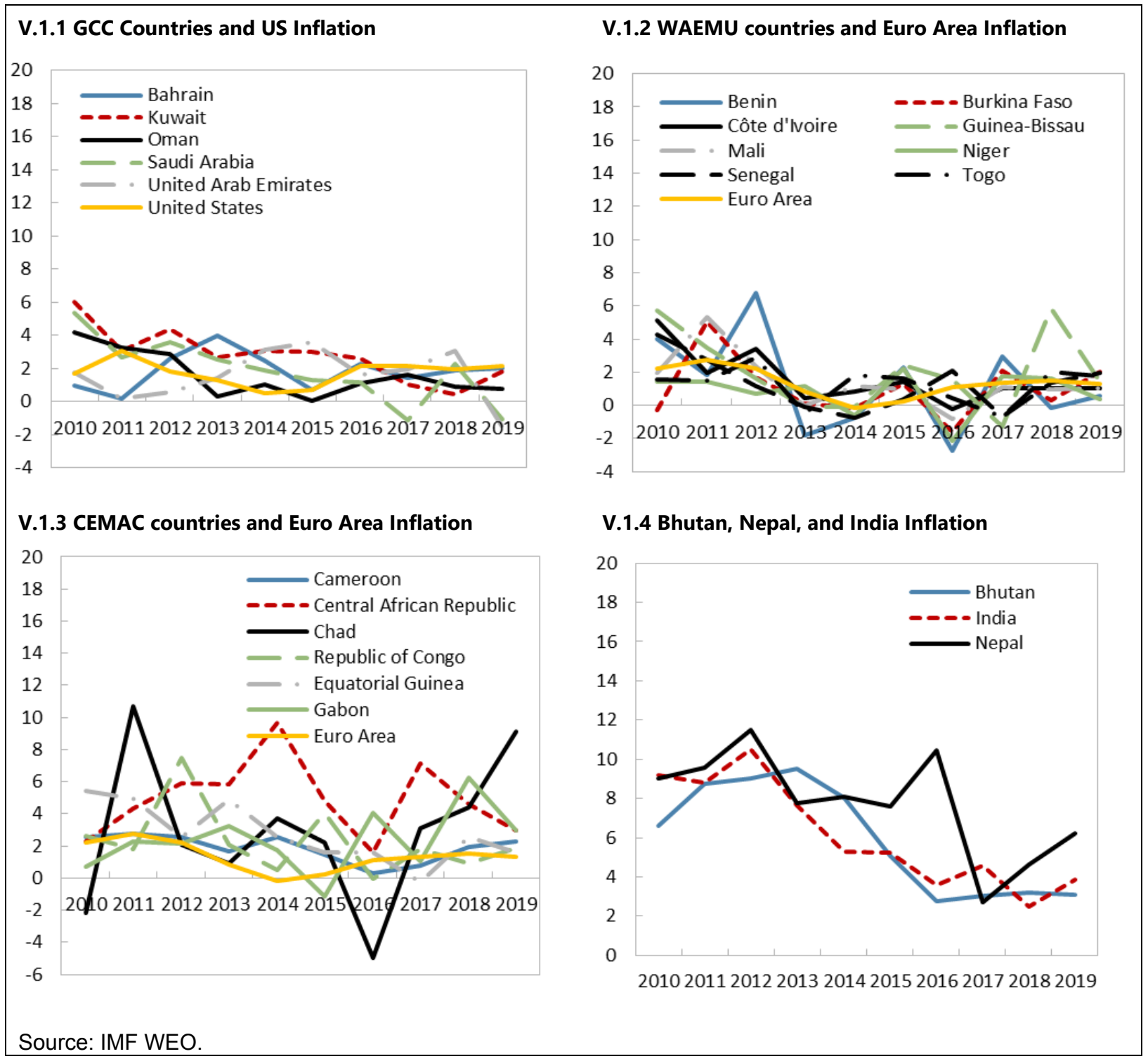




\section{REFERENCES}

Benlamine, M., A. Bulír, M. Farouki, and others, 2018. "Morocco: A Practical Approach to Monetary Policy Analysis in a Country with Capital Controls," IMF Working Paper No. 18/27, February.

Bindseil, U., 2016. "Evaluating Monetary Policy Operational Frameworks,” August.

Bordo, M.D., 2003. "Exchange Rate Regime Choice in Historical Perspective," IMF Working Paper No. 03/160, August.

Bubula, A., I. Ötker-Robe, 2003. "Are Pegged and Intermediate Exchange Rate Regimes More Crisis Prone?” IMF Working Paper No. 03/223, November.

Calvo, G.A., and C.M. Reinhart, 2000. "Fear of Floating," National Bureau of Economic Research Working Paper No. 7993, November.

, and F.S. Mishkin, 2003. "The Mirage of Exchange Rate Regimes for Emerging Market Countries," Journal of Economic Perspectives, Volume 17, No. 4, 99-118, Fall.

Carare, A., and M. Stone, 2003. "Inflation Targeting Regimes," IMF Working Paper No. 03/9, January.

Caselli, F., 2017. "Did the Exchange Rate Floor Prevent Deflation in the Czech Republic?" IMF Working Paper No. 17/206, September.

Clarida, R., J. Gali, and M. Gertler, 1998. "Monetary Policy Rules in Practice: Some International Evidence," European Economic Review 42, 1033-67.

Clinton, K., C. Freedman, M. Juillard, and others, 2015. "Inflation-Forecast Targeting: Applying the Principle of Transparency," IMF Working Paper No. 15/132, June.

Eichengreen, B., P. Masson, H. Bredenkamp, and others, 1998. "Exit Strategies: Policy Options for Countries Seeking Greater Exchange Rate Flexibility," IMF Occasional Paper No. 168.

El Hamiani Khatat, M., and R. Veyrune, 2019. "Liquidity Management under Fixed Exchange Rate with Open Capital Account," IMF Working Paper No. 19/58, March.

Franta, M., Holub T., Kral P., and others, 2015. "The Exchange Rate as an Instrument at Zero Interest Rates: The Case of the Czech Republic," Czech National Bank Research and Policy Notes, 3/2014, September. 
Freedman, C., and I. Ötker-Robe, 2010. "Important Elements for Inflation Targeting for Emerging Economies," IMF Working Paper No. 10/113, May.

Hoe Ee, K., E. Robinson, and J. Lee, 2004. "Managed Floating and Intermediate Exchange Rate Systems: The Singapore Experience," MAS Staff Paper No. 37, December.

International Monetary Fund, 2015. "Evolving Monetary Policy Frameworks in Low-Income and Other Developing Countries," October.

, 2018. "Singapore 2018 Article IV Consultation-Press Release; Staff Report; and Statement by the Executive Director for Singapore," IMF Country Report No. 18/245, July.

Kenen, P.B., 1969. "The Theory of Optimum Currency Areas: An Eclectic View," in Monetary Problems of the International Economy, R.A. Mundell and A. Swoboda (eds.). Chicago: University of Chicago Press.

Laurens, B., K. Eckhold, D. King, and others, 2015. "The Journey to Inflation Targeting: Easier Said than Done. The Case for Transitional Arrangements along the Road," IMF Working Paper No. 15/136, June.

Laxton, D., D. Rose, and A. Scott, 2009. "Developing a Structured Forecasting and Policy Analysis System to Support Inflation-Forecast Targeting (IFT)," IMF Working Paper No. 09/65, March.

Masson, P.R., M.A. Savastano, and S. Sharma, 1997. "The Scope for Inflation Targeting in Developing Countries,” IMF Working Paper 97/130, October.

McKinnon, R., 1963. "Optimal Currency Areas," American Economic Review, 53, 717-24, September.

Monetary Authority of Singapore, 2001. "Singapore's Exchange Rate Policy," February. , 2004. "Managed Floating and Intermediate Exchange Rate Systems: The Singapore Experience," Monetary Authority of Singapore Staff Paper No. 37, December. , 2013. "Monetary Policy Operations in Singapore," March.

Mundell, R., 1960. "The Monetary Dynamics of International Adjustment under Fixed and Flexible Exchange Rates", The Quarterly Journal of Economics, Vol. 74, No. 2, 22757, May. , 1961. “A Theory of Optimum Currency Areas," American Economic Review, 51, 657-61, September. 
. 1963. "Capital Mobility and Stabilization Policy under Fixed and Flexible Exchange Rates," Canadian Journal of Economics and Political Science, 29, No. 4, 475-85.

. 1968, International Economics, New York: Macmillan.

Obstfeld, M., J.C. Shambaugh, and Alan A.M. Taylor, 2004. "The Trilemma in History: Tradeoffs among Exchange Rates, Monetary Policies, and Capital Mobility," National Bureau of Economic Research Working Paper No. 10396, March.

Ostry, J.D., A.R. Ghosh, and M. Chamon, 2012. "Two Targets, Two Instruments: Monetary and Exchange Rate Policies in Emerging Market Economies," IMF Staff Discussion Note N. 12/01, February.

Ötker-Robe, I., D. Vávra, and others, 2007. "Moving to Greater Exchange Rate Flexibility, Operational Aspects Based on Lessons from Detailed Country Experiences," IMF Occasional Paper No. 256.

Parrado, E., 2004. “Singapore’s Unique Monetary Policy: How Does It Work?” IMF Working Paper No. 04/10, January. , 2004. "Inflation Targeting and Exchange Rate Rules in an Open Economy," IMF Working Paper No. 04/21, February.

Roger, S., J. Restrepo, and C. Garcia, 2009. "Hybrid Inflation Targeting Regimes," IMF Working Paper No. 09/234, October.

Shabunina A., 2017. "Monetary Policy after the Exchange Rate Floor Exit," Selected Issues Paper in IMF Country Report No. 17/169, June.

Stone, M., 2003. “Inflation Targeting Lite,” IMF Working Paper No. 03/12, January.

Svensson, L.E.O., 1997, “Inflation Targeting in an Open Economy: Strict or Flexible Inflation Targeting?”, Institute for International Economic Studies, Stockholm University, November.

Velasco, A., 1996. "When Are Fixed Exchange Rates Really Fixed?” National Bureau of Economic Research Working Paper No. 5842, November.

Yeyati, E. L., Sturzenegger, F., \& Reggio, I. 2010. "On the Endogeneity of Exchange Rate Regimes,” European Economic Review 54, 659-677. 